Atmos. Chem. Phys., 17, 10333-10348, 2017

https://doi.org/10.5194/acp-17-10333-2017

(c) Author(s) 2017. This work is distributed under

the Creative Commons Attribution 3.0 License.

\title{
Ageing and hygroscopicity variation of black carbon particles in Beijing measured by a quasi-atmospheric aerosol evolution study (QUALITY) chamber
}

\author{
Jianfei Peng ${ }^{1,2}$, Min Hu ${ }^{1,3}$, Song Guo ${ }^{1,2}$, Zhuofei Du ${ }^{1}$, Dongjie Shang ${ }^{1}$, Jing Zheng ${ }^{1}$, Jun Zheng ${ }^{2}$, Limin Zeng ${ }^{1}$, \\ Min Shao ${ }^{1}$, Yusheng $\mathrm{Wu}^{1}$, Don Collins ${ }^{2}$, and Renyi Zhang ${ }^{1,2}$ \\ ${ }^{1}$ State Key Joint Laboratory of Environmental Simulation and Pollution Control, College of Environmental Sciences and \\ Engineering, Peking University, Beijing, 100871, China \\ ${ }^{2}$ Department of Atmospheric Sciences, Texas A\&M University, College Station, Texas, 77843, USA \\ ${ }^{3}$ Beijing Innovation Center for Engineering Sciences and Advanced Technology, Peking University, Beijing, 100871, China \\ Correspondence to: Jianfei Peng (pengjianfeipku@gmail.com), Min Hu (minhu@pku.edu.cn) \\ and Renyi Zhang (renyi-zhang@geos.tamu.edu)
}

Received: 23 April 2017 - Discussion started: 9 May 2017

Revised: 17 July 2017 - Accepted: 25 July 2017 - Published: 4 September 2017

\begin{abstract}
Measurements of ageing and hygroscopicity variation of black carbon (BC) particles in Beijing were conducted using a $1.2 \mathrm{~m}^{3}$ quasi-atmospheric aerosol evolution study (QUALITY) chamber, which consisted of a bottom flow chamber through which ambient air was pulled continuously and an upper reaction chamber where ageing of $\mathrm{BC}$ particles occurred. Within the reaction chamber, transmission of the solar ultraviolet irradiation was approximately $50-60 \%$, wall loss of primary gaseous pollutants was negligible, and BC exhibited a half-lifetime of about 3-7 h. Typically, equilibrium for the primary gases, temperature and relative humidity between the reaction chamber and ambient air was established within $1 \mathrm{~h}$. Rapid growth of BC particles occurred, with an average total growth of $77 \pm 33 \mathrm{~nm}$ and average growth rate of $26 \pm 11 \mathrm{~nm} \mathrm{~h}^{-1}$. Secondary organic aerosols (SOA) accounted for more than $90 \%$ of the coating mass. The $\mathrm{O} / \mathrm{C}$ ratio of SOA was 0.5 , lower than the ambient level. The hygroscopic growth factor of $\mathrm{BC}$ particles decreased slightly with an initial thin coating layer because of $\mathrm{BC}$ reconstruction, but subsequently increased to 1.06-1.08 upon further ageing. The $\kappa$ (kappa) values for BC particles and coating materials were calculated as 0.035 and 0.040 at the subsaturation and supersaturation conditions, respectively, indicating low hygroscopicity of coated SOA on BC particles. Hence, our results indicate that initial photochemical ageing of $\mathrm{BC}$ particles leads to considerable mod-
\end{abstract}

ifications to morphology and optical properties but does not appreciably alter the particle hygroscopicity in Beijing.

\section{Introduction}

Atmospheric aerosols undergo continuous and complicated transformation during their residence time in the atmosphere. The ageing of aerosols likely resulted from both physical (i.e. coagulation, condensation, equilibrium partitioning and evaporation) and chemical (i.e. photochemical gas-phase oxidation and multiphase reactions) processes (Zhao et al., 2006; Qiu and Zhang, 2013; Zhang et al., 2015). Also, there are typically large variations in the particle properties (i.e. size, mass, chemical composition, morphology, and optical and hygroscopic parameters) during ageing, significantly influencing the aerosol impacts on visibility, human health, weather and climate (Jacobson, 2001; Guo et al., 2014). A better understanding of the ageing process of aerosols in the atmosphere is critical in atmospheric and climate research.

For example, the scientific interest in the climate effects of black carbon (BC) has remained, since BC is the strongest absorber of visible solar radiation (Wang et al., 2013). BC solar absorption represents a central issue in climate change research, since the synthesis of satellite, in situ and ground observations shows that the global solar absorption (direct 
radiative forcing or DRF) by $\mathrm{BC}$ is as much as $0.9 \mathrm{~W} \mathrm{~m}^{-2}$, second only to that of $\mathrm{CO}_{2}$ (Jacobson, 2001; Bond et al., 2013; IPCC, 2013). BC also represents an important component of air pollution for large parts of the world (Zhang et al., 2015). The properties of BC are considerably modified during ageing, including the size, mass, morphology and optical and hygroscopic parameters (Khalizov et al., 2009a, b; Xue et al., 2009a). Enhanced light absorption of BC particles during ageing not only contributes to atmospheric stabilisation and exacerbation of haze formation, but also imposes large positive radiative forcing on climate (Peng et al., 2016). Furthermore, the variation in hygroscopicity during ageing also regulates the lifetimes of $\mathrm{BC}$ particles. Hygroscopic particles efficiently serve as cloud condensation nuclei (CCN), affecting the formation, longevity and albedo of clouds (Yuan et al., 2008; Wang et al., 2011). Hence, removal of BC particles, via in-cloud scavenging and wet deposition, depends highly on the particle hygroscopicity (Bond et al., 2013). In addition, the hygroscopicity also affects the aqueous-phase reactions of atmospheric pollutants (Ervens et al., 2011; Wang et al., 2016). Previous studies using hygroscopic tandem differential mobility analyser (H-TDMA) instruments have shown that coating of hydrophilic materials significantly increases the hygroscopic growth factor of BC particles (Saathoff et al., 2003; Khalizov et al., 2009b; Guo et al., 2016). The ability of $\mathrm{BC}$ particles to form $\mathrm{CCN}$ also is enhanced after the coating of hydrophilic materials (Kuwata et al., 2007; Tritscher et al., 2011; Ma et al., 2013; Wittbom et al., 2014). The activation supersaturation depends on the particle size, hygroscopicity of coating materials and the coating thickness (Ma et al., 2013). The coating materials in the previous experiments include sulfuric acid (Zhang and Zhang, 2005; Khalizov et al., 2009b), oxidation products from biogenic and anthropogenic hydrocarbon species (Saathoff et al., 2003; Ma et al., 2013; Khalizov et al., 2013) and secondary organic aerosols (SOA) from a single-emission source (Tritscher et al., 2011). However, there still exist uncertainties for parameterisation of the BC lifetime in atmospheric models, because of insufficient constraints on the hydrophobic to hydrophilic conversion of $\mathrm{BC}$ particles under variable ambient conditions.

Atmospheric field measurements have been performed to evaluate ageing of particles on different platforms, e.g. ground, aircraft and cruise (Moffet and Prather, 2009; DeCarlo et al., 2010; Peng et al., 2014; Liu et al., 2015) and over different spatial scales (intensive campaigns or longterm measurements). Typically, a wide variety of state-ofthe-art instruments are employed to characterise the changes of the chemical and physical properties of aerosols. However, field measurements at fixed sites are affected by transport, local emissions and chemistry, and quantification of the particle parameters during ageing involves complex decoupling of the various processes (Peng et al., 2016). In particular, it is challenging to isolate the chemical processes from those related to meteorology (i.e. transport and mixing) and emissions.
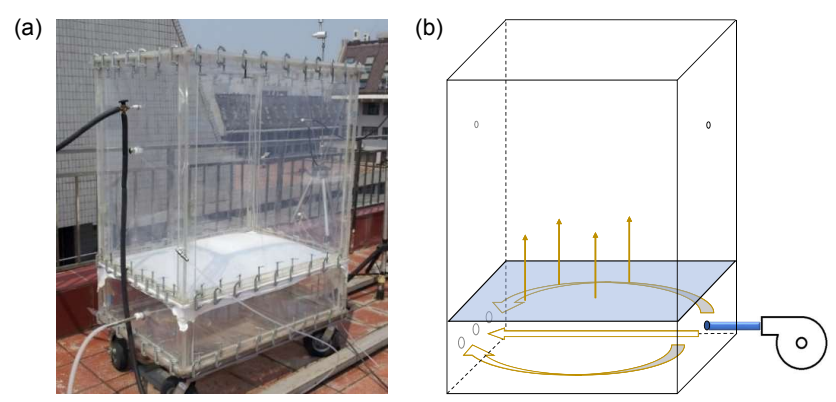

Figure 1. Photo (a) and schematic (b) of the quasi-atmospheric aerosol evolution study (QUALITY) chamber.

The methods of environmental chambers or reactors have been widely employed in atmospheric chemistry research, including photochemical oxidation of volatile organic compounds (VOCs) (Zhang et al., 2000), formation and growth of aerosols (Claeys, 2004; Kalberer, 2004), nucleation of nanoparticles (Zhang et al., 2004, 2012; Wang et al., 2010), ageing of BC particles (Zhang et al., 2008) and cloud formation (Ruehl et al., 2016). Depending on the scientific objectives, the designs of environmental chambers and reactors vary considerably (Zhang et al., 2015). However, few of the previous experimental methods have characterised the evolution of aerosols under the ambient conditions.

In this study, we present measurements of ageing and hygroscopicity variation of $\mathrm{BC}$ particles in Beijing using a quasi-atmospheric aerosol evolution study (QUALITY) chamber (Reed, 2010; Peng et al., 2016). The performance of the QUALITY chamber for mimicking the ambient gaseous concentrations (i.e. the wall loss and gas mixing rate), ultraviolet transmission and meteorology parameters (i.e. temperature and relative humidity, $\mathrm{RH}$ ) has been evaluated.

\section{Experimental method}

The $1.2 \mathrm{~m}^{3}$ QUALITY chamber was employed to study BC ageing under ambient conditions (Fig. 1). The two-layer chamber was comprised of an inner layer of $0.13 \mathrm{~mm}$ perfluoroalkoxy alkane (PFA) Teflon and an outer rigid $5.6 \mathrm{~mm}$ thick acrylic shell (Cyro Industries Acrylite, OP-4). Both Acrylite OP-4 acrylic and PFA Teflon allowed for efficient ultraviolet (UV) transmission in UV-B $(280-315 \mathrm{~nm})$ and UV-A (315-400 nm) ranges. When exposed to sunlight, the UV light transmitted through the chamber wall and initiated photochemical reactions inside the chamber.

The two individual subdivisions of the QUALITY chamber included a bottom flow chamber, through which ambient air was pulled continuously over each experiment, and an upper reaction chamber, where ageing of $\mathrm{BC}$ particles occurred (Fig. 1). The two chambers were separated by a $5 \mu \mathrm{m}$ thick semi-permeable expanded polytetrafluoroethylene (ePTFE) membrane with high degrees of chemical resistivity, 
microporosity, non-polarity and thermal stability. Gaseous species penetrated the membrane by either bulk gas flow or diffusion. The permeability of the e-PTFE was greater than $90 \%$ for nearly all the tested volatile organic components (Fig. S1 in the Supplement) and other gaseous pollutants, i.e. $\mathrm{SO}_{2}, \mathrm{NO}_{x}, \mathrm{O}_{3}$ and $\mathrm{CO}$. Particles, in contrast, were blocked from penetration into the reaction chamber. The filtration efficiency of the e-PTFE membrane was measured to be over $99.5 \%$ for particles larger than $15 \mathrm{~nm}$. During each chamber experiment, ambient air was pulled through the flow chamber continuously and gases in lower chamber permeated through the membrane into the reaction chamber. Hence, an environment that continuously captured the ambient gas concentrations without the presence of ambient particles was created inside the reaction chamber. Since the chamber was continuously exposed to ambient gas concentrations during experiments, gases lost due to reaction, deposition or adsorption to the seed aerosols within the reaction chamber were steadily replenished by the exchange with the flow chamber. Several sampling ports were set at the side of the reaction chamber for injection of seed particles or sampling during the experiment.

Seed particles were introduced into the reaction chamber via an injection line (Fig. S2). To investigate the growth of $\mathrm{BC}$ particles under ambient condition, monodisperse BC particles were injected into the QUALITY chamber. BC particles were generated by incomplete combustion of propane fuel in a custom-made laminar diffusion burner (Santoro et al., 1983; Qiu et al., 2012). The aerosol stream sequentially passed through a $300^{\circ} \mathrm{C}$ heater to evaporate the semi-volatile organic compounds in the particle phase, a Nafion dryer to remove excess moisture in the flow, and four $1 \mathrm{~m}$-long cylinders containing both alumina spherules coated with potassium hypermanganate and activated carbon to remove all the gaseous pollutants (i.e. VOCs, $\mathrm{H}_{2} \mathrm{~S}, \mathrm{SO}_{2}, \mathrm{NO}_{x}, \mathrm{O}_{3}$ ). The combined measurement of particle size distribution, density and chemical composition indicated that organics accounted for less than $10 \%$ of fresh BC mass concentration. Moreover, the single-scattering albedo (SSA) of fresh BC particles was only 0.1 , further confirming that few organic coatings existed on fresh $\mathrm{BC}$ particles after treatment. The measured removal efficiency in the cylinders for $\mathrm{SO}_{2}, \mathrm{NO}$ and $\mathrm{NO}_{2}$ were 99.2, 100 and $99.9 \%$, respectively. The aerosol stream was then introduced through an ioniser and into a differential mobility analyser (DMA, model 3081, TSI, Inc.) with stable voltage to create a monodisperse BC particle flow. A suite of high time resolution state-of-the-art aerosol instruments simultaneously measured a comprehensive set of $\mathrm{BC}$ properties throughout the $\mathrm{BC}$ ageing process (Table $\mathrm{S} 1$ in the Supplement). The particle diameter, mass, chemical composition, hygroscopicity and ability as cloud condensation nuclei (CCN) were measured by a scanning mobility particle sizer (SMPS), a differential mobility analyser-aerosol particle mass analyser (DMA-APM) system, a high-resolution time-of-flight aerosol mass spectrometer (HR-ToF-AMS), a humidified tandem differential mobility analyser (HTDMA) system, and a cloud condensation nuclei counter (CCNC), respectively. Detailed information of the instruments is provided in the Supplement and previous publications (DeCarlo et al., 2006; Khalizov et al., 2009b). Specific measurement procedures in this study are discussed below.

The DMA-APM was used to measure the effective density of BC particles (Pagels et al., 2009). Before the DMA-APM measurement, a SMPS scan was made to obtain the size distribution of particles inside the chamber. The particle size distribution was then fitted with a lognormal Gaussian distribution to derive the peak diameter. During a DMA-APM measurement, the aerosol flow passed through DMA with a fixed voltage to select particles with a fixed diameter. The APM then measured the mass distribution of the selected particles with the same diameter, and the effective density of these particles was obtained by fitting the mass distribution with a normal Gaussian distribution.

Similar to the density measurements, $\mathrm{CCN}$ activation was also measured on the basis of monodisperse particles with a peak diameter. A DMA with a fixed voltage selected particles with a peak diameter. Both a CPC and a CCN counter were placed in parallel after the DMA to simultaneously measure the total particle number concentration $\left(N_{\mathrm{CN}}\right)$ as well as the activated number concentration $\left(N_{\mathrm{CCN}}\right)$ at a fixed supersaturation. The activation fraction of the $\mathrm{BC}$ particles with peak diameter is calculated as

$f_{\mathrm{CCN}}=\frac{N_{\mathrm{CN}}}{N_{\mathrm{CCN}}}$.

Several gradients of supersaturation were set for the $\mathrm{CCN}$ counter, with each one for $6 \mathrm{~min}$. This method yielded a steeper curve of the CCN activation rate, which was employed to estimate the particle diameter with $50 \%$ activation fraction $\left(D_{50}\right)$ and the hygroscopicity parameter (kappa value).

Prior to each experiment, the QUALITY chamber was flushed by zero air for more than $40 \mathrm{~h}$ to ensure a clean condition and covered with two layers of anti-UV cloth to shield it from sunlight. At the beginning of each experiment, monodisperse $\mathrm{BC}$ particles were introduced into the chamber. The injection of $\mathrm{BC}$ particles typically lasted for 1 to $2 \mathrm{~h}$. During the injection period, zero air passed through the bottom chamber continually to remove any possible remaining gaseous pollutants by the activated carbon. After the injection, ambient air was pulled through the bottom chamber at a flow rate of about $50 \mathrm{~L} \mathrm{~min}^{-1}$ for at least half an hour in order to produce a quasi-ambient condition inside the chamber. Finally, the anti-UV cloth was removed, and BC particles underwent ageing inside the reaction chamber. A charged zeroair stream continuously passed through the space between the two chamber layers to reduce particle wall loss. Various properties of BC particles, including the particle diameter, mass, chemical composition, hygroscopicity and optical coefficients, were simultaneously measured every $0.5-1 \mathrm{~h}$. Am- 
bient particles and chamber particles were measured alternately every $30 \mathrm{~min}$. The ageing experiments lasted for about 2-6 $\mathrm{h}$ depending on the initial $\mathrm{BC}$ concentrations and ambient conditions.

The $\mathrm{BC}$ ageing experiments were conducted from $18 \mathrm{Au}-$ gust to 17 October 2013 at an urban site (PKUERS) located on the campus of Peking University in the north-western Beijing $\left(39.99^{\circ} \mathrm{N}, 116.31^{\circ} \mathrm{E}\right)(\mathrm{Hu}$ et al., 2012).

\section{Characterisation and validation of the QUALITY chamber}

\subsection{Wall loss of gases and aerosols}

To evaluate the wall loss of both particles and gases in the QUALITY chamber, different gaseous pollutants and particles were introduced into the chamber separately and the decay of their concentration inside the chamber was measured by gas analysers and SMPS, respectively. All of the ports connected to the ambient air were closed to ensure an enclosed system in the reaction chamber.

Particles with different chemical composition exhibited different wall loss rates. Monodispersed BC particles with different diameters showed a small half-lifetime $(\tau)$ of about 4-7 h (Reed, 2010). Aerosol nucleation also occurred inside the chamber, likely from organic species (Zhao et al., 2009), which corresponded to a half time of about $3.5 \mathrm{~h}$ (Fig. S3), because the nucleated particles inside the chamber was neutral with a slow electrostatic loss to the wall.

Gas species had a longer residence time inside the chamber. Toluene and isoprene did not show obvious wall loss during a 2-day experiment (Reed, 2010). $\mathrm{O}_{3}, \mathrm{SO}_{2}$ and $\mathrm{NO}_{x}$ decreased by $50 \%$ inside the chamber after more than $20 \mathrm{~h}$, suggesting slow loss. Since the loss rate of these primary gaseous pollutants was much slower than the gas exchange rate between the chamber, the loss of gases was replenished by exchange with the flow chamber.

\subsection{UV transmission}

The QUALITY chamber contained two layers of walls, an acrylic shell layer and a PFA Teflon layer. Since the QUALITY chamber used sunlight as the photochemical origin, the transmission spectra of the two-layer walls was of great importance for the photochemical reactions inside the reaction chamber.

The transmission efficiencies of each material were measured using an ultraviolet-visible (UV-vis) spectrophotometry (PerkinElmer Inc., model 552). As shown in Fig. 2, the Teflon film exhibited stable transmission efficiency of about $60 \%$ in the focused wavelength range. The Acrylic shell, however, showed very low transmission efficiency when the wavelength was shorter than $270 \mathrm{~nm}$, and high transmission efficiency (nearly $90 \%$ ) when the wavelength was longer than $300 \mathrm{~nm}$. In general, approximately $60 \%$ of the UVA

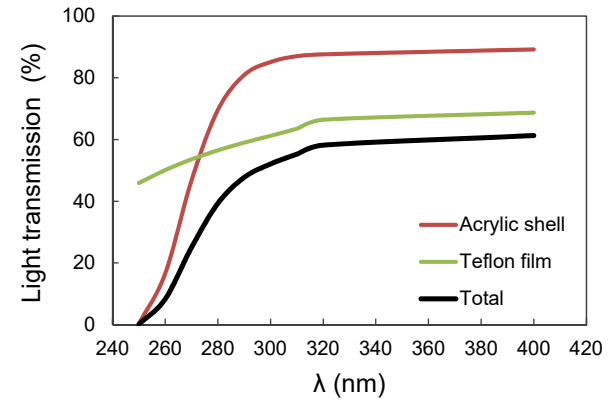

Figure 2. Light transmission spectra of the PFA Teflon film (yellow line), the acrylite shell (red line) and their total transmission in the UV range (black line).

irradiation (315-400 $\mathrm{nm}$ range) and $50 \%$ of the UVB irradiation (280-315 $\mathrm{nm}$ range) penetrated through the chamber walls, allowing photochemical processes to take place in the upper reaction chamber.

$\mathrm{A} \mathrm{NO}_{2}$-photolysis experiment was also conducted to characterise the UV transmission of QUALITY chamber. $\mathrm{NO}_{2}$ was introduced inside the chamber on a clean and sunny day. Reactions among $\mathrm{NO}_{2}, \mathrm{NO}$ and $\mathrm{O}_{3}$ according to the following reactions:

$$
\begin{aligned}
& \mathrm{NO}+\mathrm{O}_{3} \rightarrow \mathrm{NO}_{2}+\mathrm{O}_{2} \\
& \mathrm{NO}_{2} \stackrel{h v}{\longrightarrow} \mathrm{NO}+\mathrm{O} \\
& \mathrm{O}+\mathrm{O}_{2} \rightarrow \mathrm{O}_{3} .
\end{aligned}
$$

By simultaneously monitoring the concentrations of $\mathrm{NO}_{2}$, $\mathrm{NO}$ and $\mathrm{O}_{3}$ inside the chamber, the photolysis constant of $\mathrm{NO}_{2}, J\left(\mathrm{NO}_{2}\right)$ inside the chamber was estimated. The photolysis constant of $\mathrm{NO}_{2}$ inside the chamber was on average $55 \%$ of that in the ambient air, in agreement with the transmission spectra measurement and further confirming that the two-layer chamber walls allowed $50-60 \%$ of solar irradiation in the UV range into the reaction chamber.

\subsection{Gas concentrations in the reaction chamber}

To investigate the VOC concentration inside the reaction chamber after the injection of BC particles, both the chamber and ambient air were sampled with VOC canisters just before the $\mathrm{BC}$ ageing experiment started. These canisters were then analysed by a gas chromatography-mass spectrometer/flame ionisation detector (GC-MS/FID, HP inc.) system (Liu et al., 2008). The concentrations of VOCs containing four or more carbons are illustrated in Fig. 3. Slightly higher concentrations of several VOCs in the QUALITY chamber, e.g. n-butane, n-pentane, toluene, were observed compared with those in the ambient air, due to the co-injection of a small amount of VOCs together with BC particles into the chamber. Nevertheless, the average increase of the VOC concentrations was only $16 \%$ or $0.1 \mathrm{ppb}$ for all focused VOC 


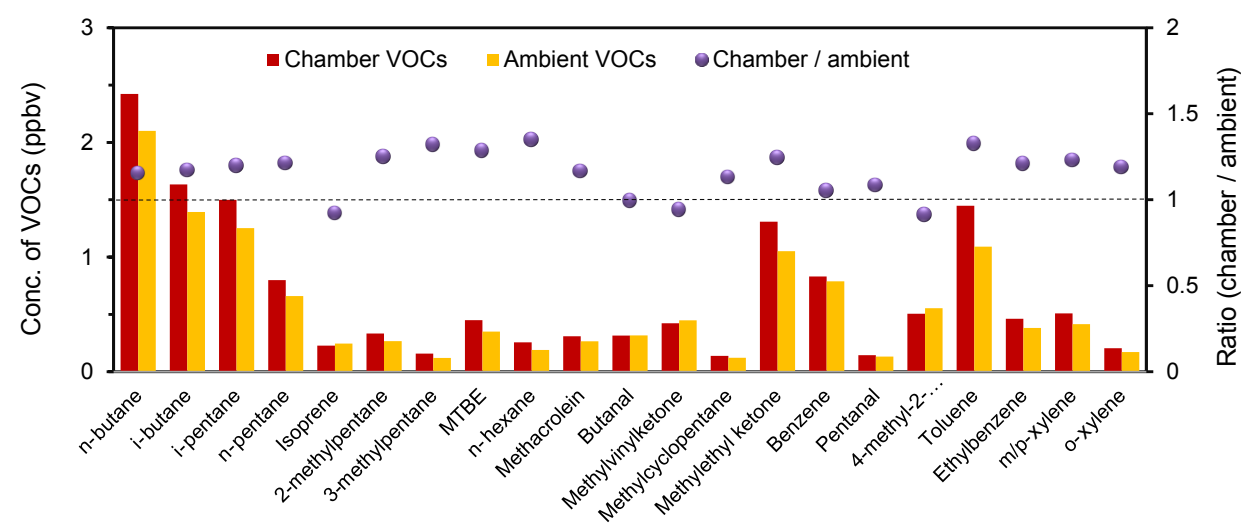

Figure 3. Comparison of VOC concentrations in the QUALITY chamber (red bar) and in the ambient air (yellow bar) before the start of BC ageing experiment. Purple cycles represent the ratio of each species in the reaction chamber to in the ambient air. Only the VOC species that contain four or more carbons with the concentration higher than $0.1 \mathrm{ppb}$ are shown in the figure.
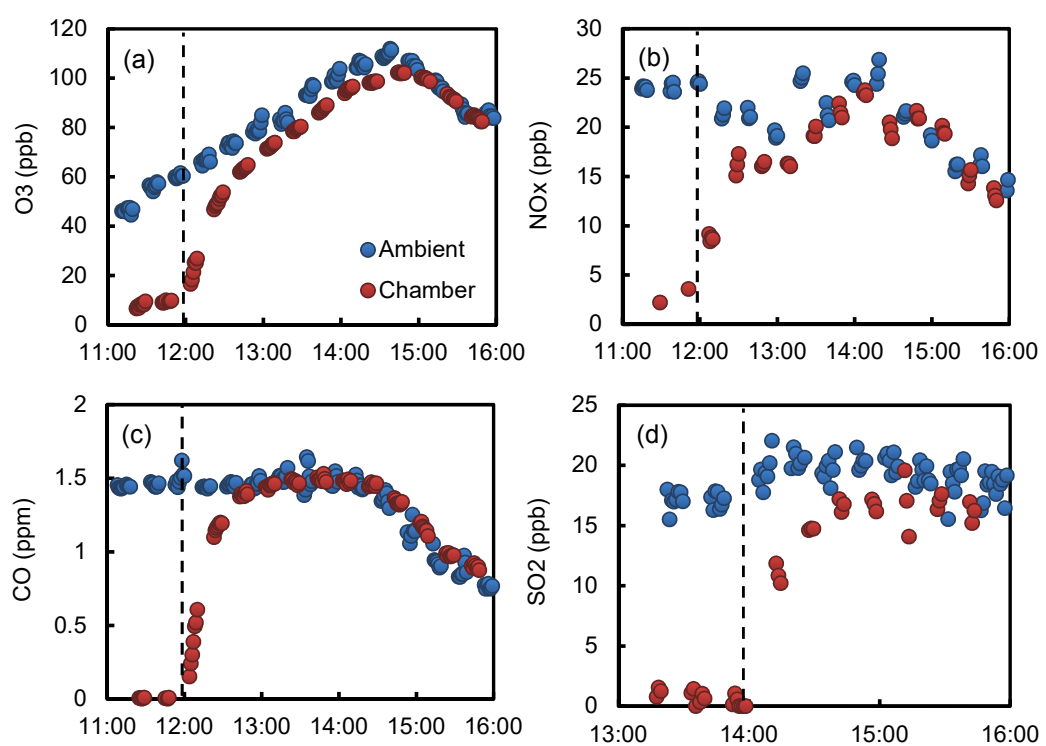

Figure 4. Concentrations of $\mathrm{O}_{3}(\mathbf{a}), \mathrm{NO}_{x}(\mathbf{b}), \mathrm{CO}(\mathbf{c})$ and $\mathrm{SO}_{2}(\mathbf{d})$ measured inside the QUALITY chamber (Red circles) and in the ambient air (blue circles). The vertical dashed lines denote the time when the ambient air started to be pulled through the bottom flow chamber and the ambient gases began to pass into the upper reaction chamber.

species, with the largest increase of $35 \%$ or $0.36 \mathrm{ppb}$, suggesting an insignificant influence of soot burner on VOC concentrations and SOA formation in the chamber.

Additional experiments were conducted to characterise the exchange timescale for gases in the QUALITY chamber. The chamber was first cleaned and flushed with zero air for $40 \mathrm{~h}$. Ambient air was then pulled through the bottom chamber (Fig. 4), and the concentrations of gaseous pollutants, including $\mathrm{O}_{3}, \mathrm{NO}_{x}, \mathrm{CO}$ and $\mathrm{SO}_{2}$, were measured alternatively in the ambient air and in the upper chamber. At the beginning of the experiment the concentrations of all gaseous species were lower than those in the ambient air. After ambient air was pulled through the bottom chamber (labelled as the black dots in Fig. 4), the concentrations of the gaseous pollutants in the reaction chamber increased sharply. For example, the $\mathrm{CO}$ concentration inside the chamber was approximate $70 \%$ of the ambient concentration after 30 min mixing. The concentrations inside the chamber and ambient air exhibited little difference after $1 \mathrm{~h}$ mixing (Fig. 4c). Hence, the QUALITY chamber replicated the ambient gas concentrations well. The gas exchange rate between the bottom and reaction chambers was calculated to be approximately $0.06 \mathrm{~min}^{-1}$.

\subsection{Temperature and RH}

The greenhouse effect for an outdoor chamber typically increases the temperature and decreases the $\mathrm{RH}$ inside the chamber. For the QUALITY chamber, however, heat pro- 

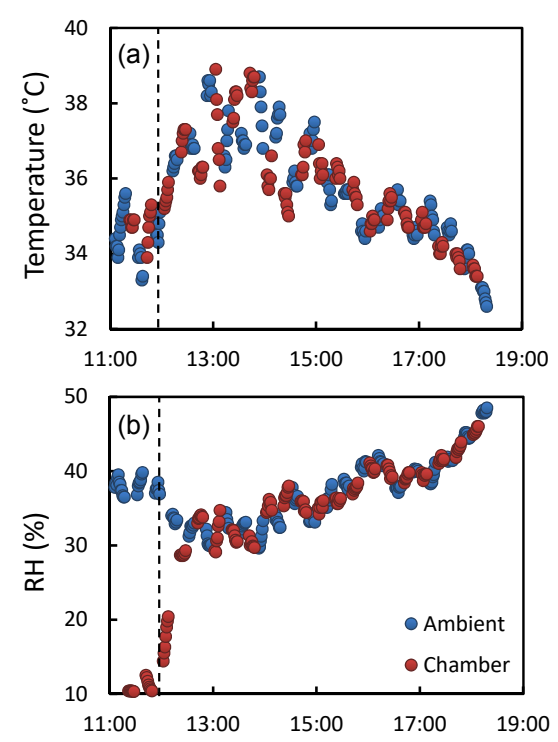

Figure 5. Temperature (a) and RH (b) measured inside the QUALITY chamber (Red circles) and in the ambient air (blue circles). The temperature and $\mathrm{RH}$ were measured by probes placed in the sampling tube adjacent to the chamber. The vertical dashed lines denote the time when the ambient air started to be pulled through the bottom flow chamber and the ambient gases began to pass into the upper reaction chamber.

duced by the greenhouse effect inside the chamber was effectively taken away as the ambient air continuously passed through the bottom chamber and exchanged with air in the upper chamber. As illustrated in Fig. 5, there was little difference in temperature or RH inside and outside the chamber, when the chamber experiments lasted for more than $1 \mathrm{~h}$, suggesting that the QUALITY chamber effectively captured the ambient temperature and $\mathrm{RH}$.

\subsection{Sulfuric acid production}

Though gaseous pollutants such as $\mathrm{SO}_{2}, \mathrm{O}_{3}, \mathrm{NO}_{x}$ and VOCs penetrated into the reaction chamber from the bottom chamber through the semi-permeable membrane, low volatile and sticky gases, i.e. sulfuric acid, were unlikely to penetrate through the membrane (Fortner et al., 2004). To characterise sulfuric acid production inside the chamber, we conducted an experiment by pulling ambient air into the bottom chamber while injecting $\mathrm{SO}_{2}$ directly into the reaction chamber. The experiment was conducted around noon on a clear day when the $\mathrm{O}_{3}$ concentration was around $50 \mathrm{ppb}$. A custom-made atmospheric pressure-ion drift chemical ionisation mass spectrometry (AP-ID-CIMS) (Fortner et al., 2004; Zheng et al., 2010) was used to directly measure the concentration of gaseous sulfuric acid. Figure 6 shows a good correlation between $\mathrm{SO}_{2}$ and gaseous $\mathrm{H}_{2} \mathrm{SO}_{4}$ inside the chamber, suggesting that the QUALITY chamber simulated the formation of

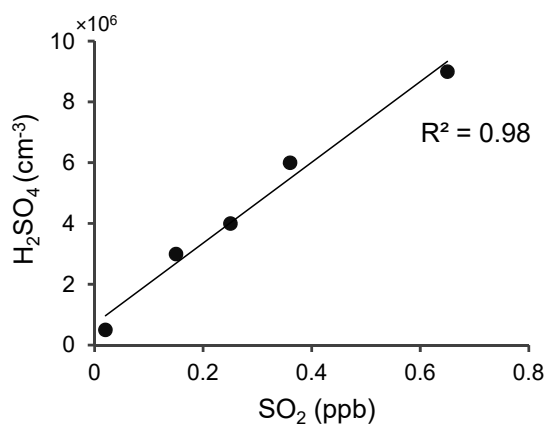

Figure 6. Sulfuric acid concentration as a function of $\mathrm{SO}_{2}$ concentration inside the chamber.

low volatile gaseous species well and hence the photochemical processes.

\section{BC evolution in the QUALITY chamber}

Time series of the ambient PM, gas and meteorology parameters of ambient air during the chamber experiment period are illustrated in Fig. 7. Except for the last experiment conducted on 17 October, all experiments were conducted between 18 August and 21 September 2013. During this period in Beijing, strong photochemical reactions and frequent heavy pollution events occurred (Huang et al., 2010; Zhao et al., 2013). Temperature and RH during this period (18 August to 21 September) varied from 24 to $38^{\circ} \mathrm{C}$ and from 20 to $90 \%$, respectively. The average concentrations of $\mathrm{PM}_{2.5}, \mathrm{SO}_{2}$ and $\mathrm{NO}_{x}$ were $60 \pm 45 \mu \mathrm{g} \mathrm{m}^{-3}, 3.2 \pm 2.6 \mathrm{ppb}$ and $33.9 \pm 20.9 \mathrm{ppb}$.

The red shaded areas in Fig. 7 represent the periods of the nine chamber experiments. Most of the chamber experiments were conducted in the afternoon of relatively clean and sunny days, when strong solar radiation led to fast photochemical reactions. There were two experiments conducted on polluted days, e.g. the experiments on 22 October and 11 September. Table 1 summarises the conditions of the experiments. Total $10 \mathrm{BC}$ ageing experiments were conducted, including four experiments using $\mathrm{BC}$ particles with initial mobility diameter of $100 \mathrm{~nm}$, three experiments using $150 \mathrm{~nm}$ particles and three using $220 \mathrm{~nm}$ BC particles. The average concentrations of $\mathrm{PM}_{2.5}$ and $\mathrm{NO}_{x}$ over each chamber experiment were 9 to $69 \mathrm{\mu g} \mathrm{m}^{-3}$ and 9 to $41 \mathrm{ppb}$, respectively. The concentrations of VOCs, such as toluene and $m / p$ xylene, were relatively low during most of the experiments compared with severe pollution episodes in Beijing (Guo et al., 2014). $J\left(\mathrm{O}^{1} \mathrm{D}\right)$ and $\mathrm{O}_{3}$ exhibited higher values during the chamber experiments. The average $J\left(\mathrm{O}^{1} \mathrm{D}\right)$ values and $\mathrm{O}_{3}$ concentrations ranged from $3.2 \times 10^{-6}$ to $21.1 \times 10^{-6} \mathrm{~s}^{-1}$ and from 26 to $92 \mathrm{ppb}$, respectively. 

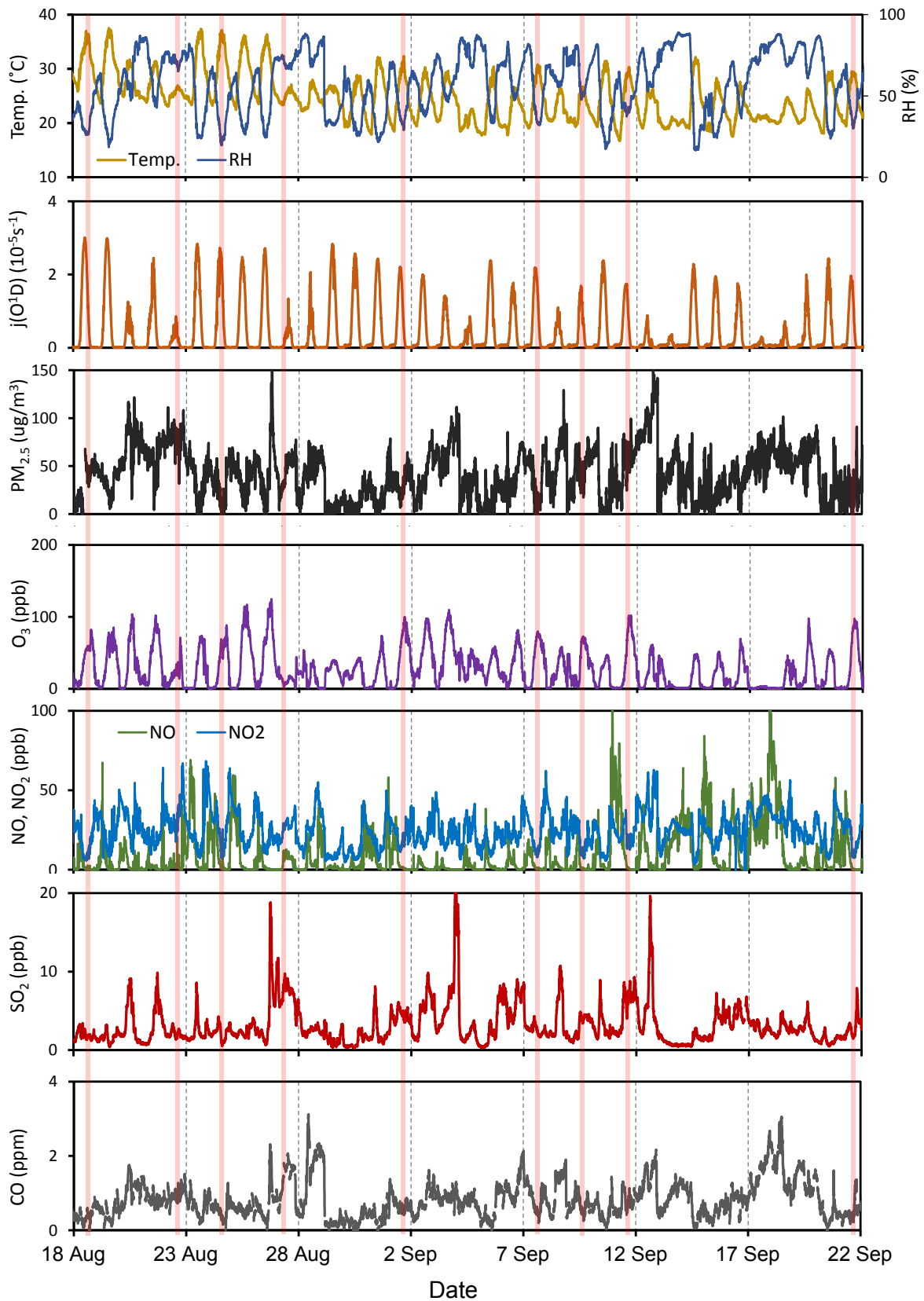

Figure 7. Time series of ambient pollutant concentrations and meteorological parameters during the experimental period in Beijing. Red bars indicate periods when $\mathrm{BC}$ ageing experiments were conducted.

\subsection{BC growth}

To quantify the growth of $\mathrm{BC}$ particles, several parameters were used to describe the properties of BC particles, including the effective density, mobility diameter and mass equivalent diameter. Material density $\left(\rho_{\mathrm{m}}\right)$ is the average density of the solid and liquid material in the particle. Assuming that the volume of the species coexisting in an individual particle does not change upon mixing, the density of an internally mixed particle is calculated using the material densities and mass concentrations of particulate constituents (DeCarlo et al., 2004; Pagels et al., 2009):

$\rho_{\mathrm{m}}=\frac{\sum_{\text {species }} m_{i}}{\sum_{\text {species }} V_{i}}=\frac{\sum_{\text {species }} m_{i}}{\sum_{\text {species }} \frac{m_{i}}{\rho_{i}}}=\frac{\sum_{\text {species }} \mathrm{MC}_{i}}{\sum_{\text {species }} \frac{\mathrm{MC}_{i}}{\rho_{i}}}$,

where $\rho_{i}$ is the material density of species $i, V_{i}$ is its volume, $m_{i}$ is its mass, and $\mathrm{MC}_{i}$ is its mass concentration. This approach is based on the assumption that there is no void 
Table 1. Summary of ambient conditions for BC ageing experiments conducted in Beijing. The $\mathrm{PM}_{2.5}$, gas concentrations and meteorological condition were averaged from the entire experimental time. $D_{\mathrm{m}}$ and $T$ represent the mobility diameter and temperature.

\begin{tabular}{|c|c|c|c|c|c|c|c|c|c|c|c|c|c|}
\hline \multirow{3}{*}{ No. } & \multirow[t]{3}{*}{ Date } & \multicolumn{2}{|c|}{ Time } & \multirow{3}{*}{$\begin{array}{r}\text { Initial } D_{\mathrm{m}} \\
(\mathrm{nm})\end{array}$} & \multirow{3}{*}{$\begin{array}{r}\mathrm{PM}_{2.5} \\
\left(\mu \mathrm{g} \mathrm{m}^{-3}\right)\end{array}$} & \multirow{3}{*}{$\begin{array}{r}J\left(\mathrm{O}^{1} \mathrm{D}\right) \\
\left(10^{-6}\right)\end{array}$} & \multicolumn{5}{|c|}{ Gas concentration (ppb) } & \multirow{2}{*}{\multicolumn{2}{|c|}{$\begin{array}{l}\text { Meteorological } \\
\text { conditions }\end{array}$}} \\
\hline & & Start & End & & & & Toluene & Xylene & $\mathrm{SO}_{2}$ & $\mathrm{NO}_{x}$ & $\mathrm{O}_{3}$ & & \\
\hline & & & & & & & & & & & & $T\left({ }^{\circ} \mathrm{C}\right)$ & $\mathrm{RH}(\%)$ \\
\hline 1 & 18 Aug & $12: 41$ & $14: 47$ & 95 & 43 & 19 & 0.49 & 0.13 & 1.7 & 8.8 & 56 & 35 & 27 \\
\hline 2 & 22 Aug & $13: 32$ & $16: 51$ & 96 & 69 & 3.7 & 3.41 & 0.78 & 2 & 36.1 & 26 & 26 & 69 \\
\hline 3 & $7 \mathrm{Sep}$ & $12: 40$ & $14: 52$ & 97 & 12 & 17.5 & 0.71 & 0.17 & 2.7 & 10.2 & 75 & 30 & 35 \\
\hline 4 & 9 Sep & $13: 13$ & $17: 06$ & 97 & 40 & 6.3 & 0.77 & 0.21 & 4 & 11 & 68 & 26 & 50 \\
\hline 5 & 1 Sep & $13: 19$ & $16: 13$ & 147 & 27 & 11.6 & 0.76 & 0.19 & 4.6 & 19.9 & 83 & 31 & 33 \\
\hline 6 & 11 Sep & $13: 50$ & $17: 25$ & 147 & 57 & 6.1 & 1.57 & 0.39 & 6.7 & 17.1 & 92 & 29 & 42 \\
\hline 7 & $21 \mathrm{Sep}$ & $15: 31$ & $17: 41$ & 146 & 30 & 2.1 & 0.75 & 0.29 & 2 & 10.6 & 90 & 28 & 37 \\
\hline 8 & 24 Aug & $11: 37$ & $16: 06$ & 216 & 8.8 & 21.1 & 0.98 & 0.3 & 1.7 & 15.6 & 57 & 36 & 25 \\
\hline 9 & $5 \mathrm{Sep}$ & 14:06 & $16: 44$ & 220 & 12 & 8.3 & 0.45 & 0.2 & 2.2 & 14.6 & 54 & 29 & 35 \\
\hline 10 & $17 \mathrm{Oct}$ & $12: 54$ & $17: 13$ & 224 & 57 & 3.2 & - & - & 13.8 & 41 & 34 & 18 & 30 \\
\hline
\end{tabular}

space enclosed within the particle envelope. Hence, the material density is larger than the true particle density with internal voids in particles. In this study, $\rho_{\mathrm{m}}$ is calculated from the chemical composition of the coating materials measured by AMS. A value of 1.35 for the material density of SOA formed during the chamber experiment was obtained by directly measuring the density of newly formed particles inside the chamber via a DMA-APM system.

Effective density $\left(\rho_{\text {eff }}\right)$ is defined as the ratio of the measured particle mass $\left(m_{\mathrm{p}}\right)$ to the particle volume calculated assuming a spherical particle with a diameter equal to the measured mobility diameter $\left(D_{\mathrm{m}}\right)$ (DeCarlo et al., 2004; Pagels et al., 2009; Xue et al., 2009b):

$\rho_{\mathrm{eff}}=\frac{6 m_{\mathrm{p}}}{\pi D_{\mathrm{m}}^{3}}$

In this study, $m_{\mathrm{p}}$ of BC particles was measured by the APM and mobility diameter $\left(D_{\mathrm{m}}\right)$ was measured by the DMA. The effective density reflects the information on both particle density and shape. If particles are spherical in the absence of internal void, the effective density equals the material density. If particles are non-spherical, the calculated volume and volume concentration are larger than the true values, and the effective density is lower than the true particle and the material density.

Figure 8 exhibits the change of particle density and diameter in three typical $\mathrm{BC}$ ageing experiments using particles with the initial diameters of 100, 150 and $220 \mathrm{~nm}$ (experiments 4,5 and 9 in Table 1). The average $\mathrm{PM}_{2.5}$ concentrations in these experiments were 40,27 and $12 \mu \mathrm{g} \mathrm{m}^{-3}$, suggesting relatively clean conditions during the experiments. In all three experiments, ageing of $\mathrm{BC}$ particles occurred between 13:00-14:00 and 17:00 local time. The highest $J\left(\mathrm{O}^{1} \mathrm{D}\right)$ value varied from 1.7 to $2.4 \times 10^{-5} \mathrm{~s}^{-1}$ and decreased gradually over the experiment period. Average $\mathrm{O}_{3}$ concentrations during the three experiments were 68,83 and
$54 \mathrm{ppb}$, indicating strong oxidation during the experiment periods.

For three initial $D_{\mathrm{m}}$ of 100,150 and $200 \mathrm{~nm}$, the ranges of effective density of fresh $\mathrm{BC}$ particles in each experiment were $0.43-0.50,0.34-0.34$ and $0.24-0.32 \mathrm{~g} \mathrm{~cm}^{-3}$, respectively, indicating highly fractal $\mathrm{BC}$ aggregates (Zhang et al., 2008). The small variation for particles with the same $D_{\mathrm{m}}$ also demonstrates the consistency of fresh BC morphology in different experiments. After ageing of $1 \mathrm{~h}, \rho_{\text {eff }}$ of BC particles in the three experiments increased to approximately $1.2 \mathrm{~g} \mathrm{~cm}^{-3}$, suggesting that formation of the secondary components changed the morphology from chain-like BC particles to a more compact shape (Zhang et al., 2008; Peng et al., 2016). The morphology change was further confirmed by a decrease of $D_{\mathrm{m}}$, particularly for larger BC particles that were more fractal than smaller $\mathrm{BC}$ particles.

As the $D_{\mathrm{m}}$ is largely influenced by the particle morphology, we utilised the parameter of mass equivalent diameter $\left(D_{\text {me }}\right)$ to describe the growth of particles. Based on the mobility diameter $\left(D_{\mathrm{m}}\right)$, material density $\left(\rho_{\mathrm{m}}\right)$ and effective density $\left(\rho_{\text {eff }}\right), D_{\text {me }}$ is calculated assuming that particles are compact and have a spherical morphology (DeCarlo et al., 2004):

$D_{\mathrm{me}}=\sqrt[3]{\frac{\rho_{\mathrm{eff}}}{\rho_{\mathrm{m}}}} D_{\mathrm{m}}$.

The change in the mass equivalent diameter $\left(\Delta D_{\mathrm{me}}\right)$ during $\mathrm{BC}$ ageing is defined as the total coating thickness, and the ratio of the total coating thickness to the initial mass equivalent diameter $\left(\Delta D_{\mathrm{me}} / D_{\mathrm{me}, 0}\right)$ is defined as the coating fraction.

The initial $D_{\text {me }}$ of fresh BC particles with initial $D_{\mathrm{m}}$ of 100,150 and $220 \mathrm{~nm}$ were 61,84 and $114 \mathrm{~nm}$, respectively. In contrast to the mobility diameter, $D_{\text {me }}$ increased continuously during the entire experiment. After $3-4 \mathrm{~h}, D_{\mathrm{me}}$ in the three experiments increased to 133, 169 and $197 \mathrm{~nm}$ (Fig. 8), with the average growth rates of 19,29 and $31 \mathrm{nmh}^{-1}$. 

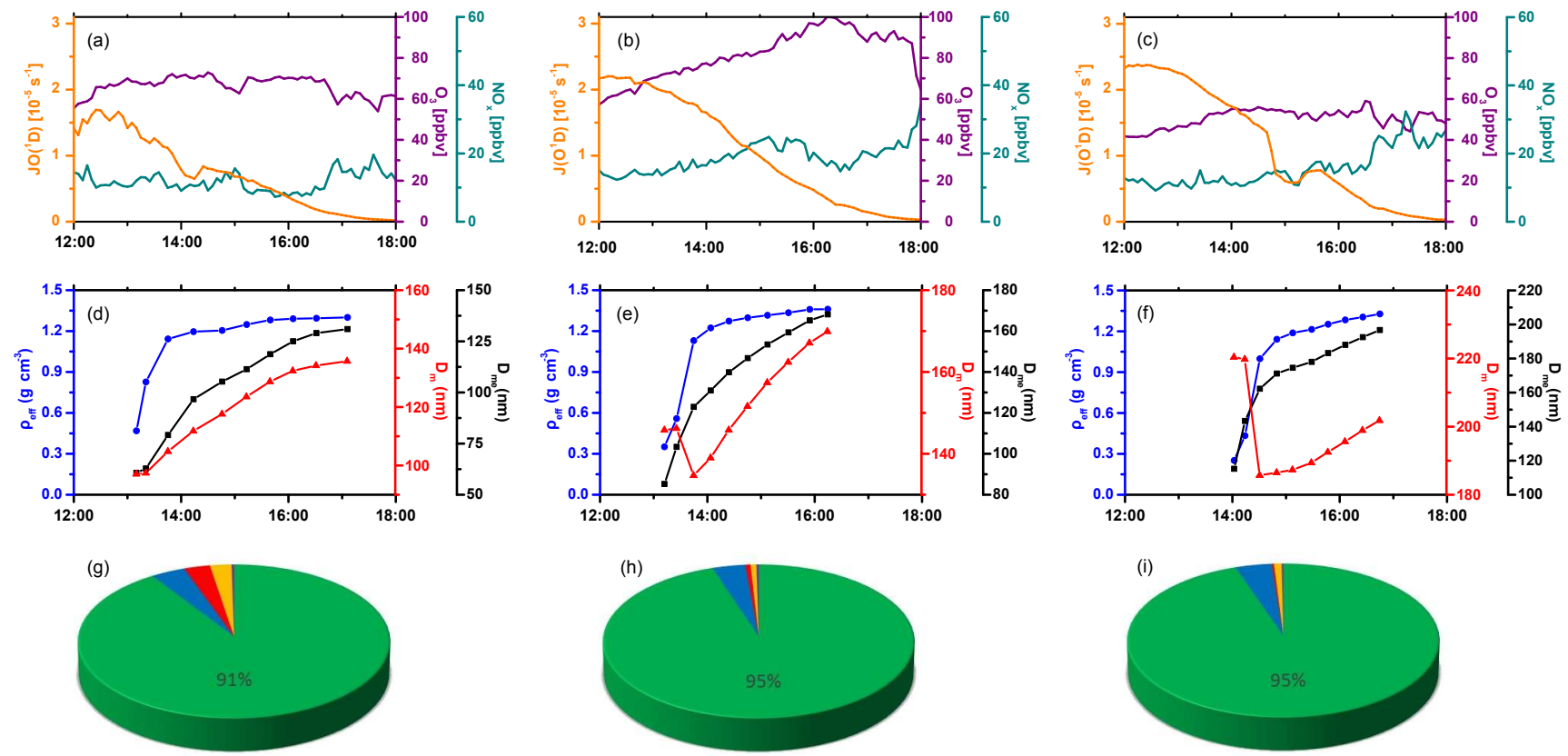

Figure 8. Ambient condition (a, b, c), changes of diameter and density of BC particle (d, e, f), and the chemical composition of coating materials $(\mathbf{g}, \mathbf{h}, \mathbf{i})$ during three typical ageing experiments. Panels (a, d) correspond to experiment 4, (b, e) correspond to experiment 5, and (c, e) correspond to experiment 9. $D_{\mathrm{m}}$ is the peak mobility diameter of BC particles, $\rho_{\mathrm{eff}}$ is the best-fit effective density of BC particles with the mobility diameter $D_{\mathrm{m}}, D_{\mathrm{me}}$ is the mass equivalent diameter of $\mathrm{BC}$ particles, and $J\left(\mathrm{O}^{1} \mathrm{D}\right)$ represents the measured photolysis rate constant for $\mathrm{O}\left({ }^{1} \mathrm{D}\right)$. The colours of green, blue, red, yellow and purple in the pie charts represent organics, nitrate, sulfate, ammonium and chlorine, respectively. The numbers in panels $(\mathbf{g}, \mathbf{h}, \mathbf{i})$ are the mass fraction of organics.

Higher growth rates in $D_{\text {me }}$ occurred around noontime, when the $J\left(\mathrm{O}^{1} \mathrm{D}\right)$ value was higher and the photochemical reaction was stronger. In contrast, a much lower growth rate was observed during the late afternoon or with cloud coverage (as shown in Fig. 8c at 15:00), indicating that the growth was driven by photochemical reactions.

The increases of the particle density and diameter in all the experiments are summarised in Table 2. Fast ageing of $\mathrm{BC}$ particles occurred in all experiments. The total growth of $D_{\text {me }}$ ranged from 40 to $152 \mathrm{~nm}$ within $3-6 \mathrm{~h}$, with an average growth of $73 \mathrm{~nm}$. The average growth rate was $26 \pm 11 \mathrm{~nm} \mathrm{~h}^{-1}$, demonstrating large secondary production under the ambient conditions in Beijing. The largest growth rate $\left(\Delta D_{\mathrm{me}}=152 \mathrm{~nm}\right)$ was observed in experiment 8 , when the solar irradiation was the strongest among all experiments (Table 2).

Correlation analysis was made between the average growth rate of $\mathrm{BC}$ particles $\left(\Delta D_{\mathrm{me}} / \Delta t\right)$ with $\mathrm{O}_{3}, \mathrm{PM}_{2.5}$, $J\left(\mathrm{O}^{1} \mathrm{D}\right)$ and temperature during the different experiments (Fig. S4). The growth rate of $\mathrm{BC}$ particles exhibits no correlation with $\mathrm{O}_{3}$ concentration $\left(R^{2}=0.00\right)$, weak negative correlation with $\mathrm{PM}_{2.5}$ concentration $\left(R^{2}=0.25\right)$ and strong positive correlations with $J\left(\mathrm{O}^{1} \mathrm{D}\right)\left(R^{2}=0.80\right)$ and temperature $\left(R^{2}=0.67\right)$, indicating the importance of photochemical production on the $\mathrm{BC}$ coating materials.

\subsection{Chemical composition of coating materials}

Particle composition measurements by AMS during chamber experiments reveal a majority of coating materials (above $90 \%$ ) as SOA (Fig. 8). The concentration of SOA inside the chamber reached up to $9 \mu \mathrm{g} \mathrm{m}^{-3}$ in several experiments, suggesting fast formation of SOA via gas phase oxidation of VOCs. The SOA formation in Beijing is likely attributed to a large amount of anthropogenic aromatic VOCs (Peng et al., 2017).

The elemental compositions of OA inside the chamber, i.e. the oxygen to carbon $(\mathrm{O} / \mathrm{C})$ ratio and the hydrogen to carbon $(\mathrm{H} / \mathrm{C})$ ratio, were calculated based on the updated ambient calibrations (He et al., 2011; Canagaratna et al., 2015). The $\mathrm{H} / \mathrm{C}$ and $\mathrm{O} / \mathrm{C}$ ratios of organics for coating on $\mathrm{BC}$ particles exhibit notable trends during the ageing process. Figure 9a shows an example of the evolution of $\mathrm{H} / \mathrm{C}$ and $\mathrm{O} / \mathrm{C}$ ratios in experiment 8 . The data were corrected for the $\mathrm{CO}_{2}$ concentration in the chamber, which were introduced into the chamber with BC particles and influenced the abundance of $m / z=28$ and 44 in the AMS mass spectra. The $\mathrm{H} / \mathrm{C}$ ratio decreased from 1.73 to 1.45 over $6 \mathrm{~h}$. Accordingly, the $\mathrm{O} / \mathrm{C}$ ratio increased from 0.32 to 0.50 during the same time, revealing that further oxidation of SOA occurred in the latter part of the experiment. The lower final $\mathrm{O} / \mathrm{C}$ ratio in the chamber experiment $(0.5)$ than that under the ambient con- 
Table 2. Summary of particle properties for BC ageing experiments conducted in Beijing. $D_{\mathrm{m}}, \rho_{\mathrm{eff}}$ and $D_{\mathrm{me}}$ represent the mobility diameter, effective density and mass equivalent diameter.

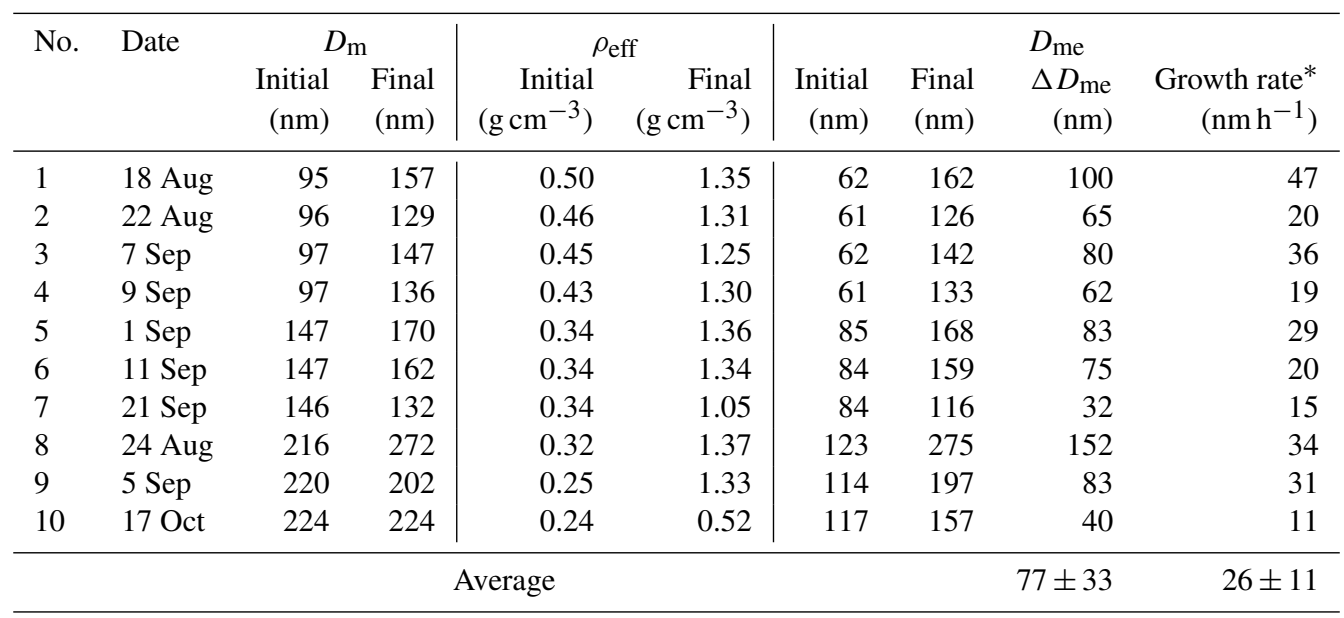

* The growth rate is calculated using the data between 12:00 and 17:00 for each experiment.

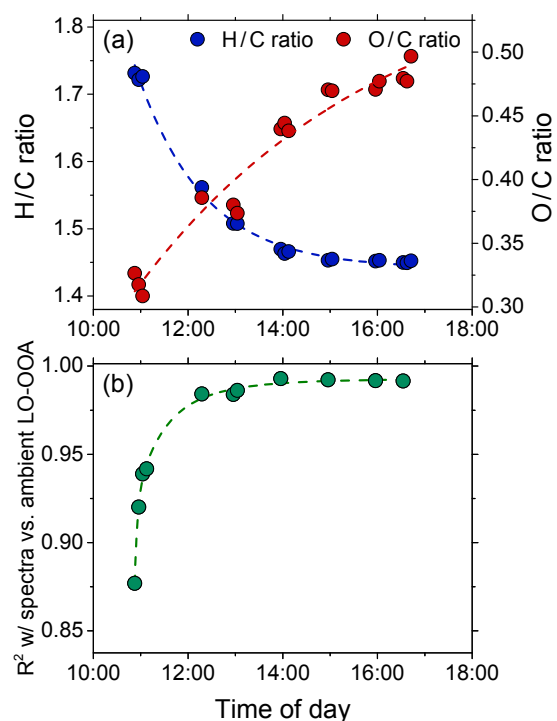

Figure 9. The evolution of organic aerosols inside the chamber during an ageing experiment (no. 8) in Beijing. Panel (a) the $\mathrm{H} / \mathrm{C}$ and $\mathrm{O} / \mathrm{C}$ ratios of organics on aged $\mathrm{BC}$ particles, (b) the correlation coefficients $\left(R^{2}\right)$ between the evolving total OA spectra in chamber experiment and the LO-OOA spectra derived from the Beijing field data set.

ditions ( $\mathrm{Hu}$ et al., 2016) implies that there is oxidation on a longer timescale or by the aqueous pathway for the formation of highly oxidised SOA in the ambient air (Zhang et al., 2015).

Furthermore, the mass spectra of OA inside the chamber shows strong correlation with the less-oxidised oxygenated organic aerosols (LO-OOA) derived from field measurements in Beijing (Hu et al., 2016), which likely arose from oxidation of aromatic VOCs emitted from vehicles (Peng et al., 2017). The correlation coefficient $\left(R^{2}\right)$ was initially 0.88 and rose to 0.99 sharply (Fig. 9b), indicating that the chamber simulated the formation of LO-OOA well.

In our study, the secondary inorganic aerosols, i.e. sulfate, nitrate and ammonium, only accounted for less than $10 \%$ of the coating materials on BC particles. This is consistent with the previous studies showing that the concentration of organics is much larger than those of sulfate and nitrate during the early stage of haze development in Beijing (Guo et al., 2014). The low observed sulfate concentration in this study suggests that the gas phase formation of sulfuric acid was unimportant under our experimental conditions. However, it has been shown that the aqueous-phase reactions represent the dominate pathway for sulfate formation in Beijing (Guo et al., 2010; Wang et al., 2016).

$\mathrm{NO}_{2}$ has a higher reaction coefficient with the $\mathrm{OH}$ radical $\left(8 \times 10^{-12} \mathrm{~cm}^{3}\right.$ molecule $\left.{ }^{-1} \mathrm{~s}^{-1}\right)$ than $\mathrm{SO}_{2}$ (Zhang et al., 2015). Nitrate acid formed in the gas phase is transformed into nitrate salts by the reaction with ammonia in the equilibrium process:

$\mathrm{HNO}_{3}(\mathrm{~g})+\mathrm{NH}_{3}(\mathrm{~g}) \leftrightarrow \mathrm{NH}_{4} \mathrm{NO}_{3}(\mathrm{~s})$

The equilibrium of this reaction is highly dependent on ambient temperature and RH (Zheng et al., 2008). In this study, chamber experiments were conducted in the afternoon with high temperature and low RH (Table 1), which shifted the thermodynamic equilibrium to the gas phase.

\subsection{Hygroscopicity evolution}

\subsubsection{HTDMA measurement}

The hygroscopic growth factors (HGF) of particles in each experiment were continuously measured by the HTDMA 

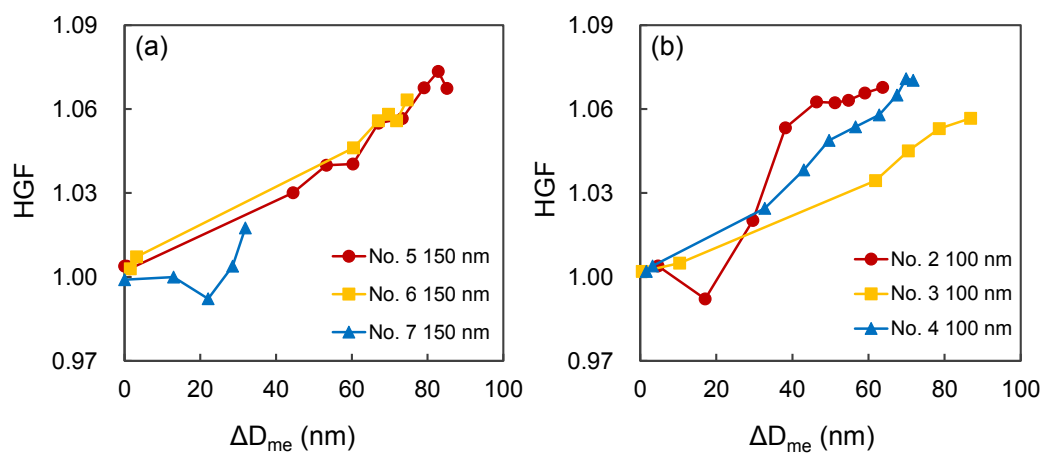

Figure 10. Evolution of hygroscopic growth factors (HGF) of BC particles during ageing as a function of $\Delta D_{\text {me. }}$ (a) Three experiments with $100 \mathrm{~nm}$ BC particles, (b) three experiments with $150 \mathrm{~nm}$ BC particles. Different colours in each figure represent different experiments. Hygroscopicity measurement is not available for experiment 1 .

system and corrected for the reference "dry" diameters:

$\mathrm{HGF}=\frac{D_{\mathrm{wet}, t} / D_{\mathrm{m}, t}}{D_{\mathrm{dry}, 0} / D_{\mathrm{m}, 0}}$,

where $D_{\mathrm{m}}$ is the mobility diameter of fresh or coated particles at dry condition, $D_{\text {dry }}$ is the mobility diameter of particles after experiencing a low humidity (below $30 \%$ ) cycle in HTDMA, and $D_{\text {wet }}$ is the mobility diameter of particles after experiencing a high humidity cycle $(87 \%)$ in HTDMA.

Figure 10 shows the hygroscopicity variation of $\mathrm{BC}$ particles with the initial mobility diameter $\left(D_{\mathrm{m}, 0}\right)$ of 100 and $150 \mathrm{~nm}$. The measured HGF of $0.999-1.004$ for fresh BC particles suggests high hydrophobicity, consistent with the previous studies (Khalizov et al., 2009b; Weingartner et al., 1997). After being exposed to sunlight and ambient gaseous pollutants for several hours, the HGF of these BC particles increased to $1.02-1.08$ at the end of each experiment. The HGF value varied with the total growth $\left(\Delta D_{\mathrm{me}}\right)$ of $\mathrm{BC}$ particles, but was constant at the same $\Delta D_{\text {me }}$ for different experiments (Fig. 10). The final HGF values shown in Fig. 10 (1.02-1.08) were much lower than those in previous laboratory studies (Khalizov et al., 2009b; Tritscher et al., 2011) but similar to the low hygroscopic fraction in field observations (Swietlicki et al., 2008), even for growth of particle size up to $90 \mathrm{~nm}$ in our experiments.

The HGF is affected by many factors, e.g. the particle chemical composition and morphology as well as RH (Qiu et al., 2012). The hygroscopicity of BC particles coated with inorganic components, i.e. sulfuric acid (Khalizov et al., 2009b), is significantly higher than those coated with organic compounds (Tritscher et al., 2011). In this study, the major component of the coating substance was LO-OOA with a $\mathrm{O} / \mathrm{C}$ ratio of about 0.5 . The low oxygen content of SOA coated on BC particles explains the low hygroscopicity (Jimenez et al., 2009), indicating that the coating of BC particles during the early stage of haze development in Beijing does not considerably increase the particle hygroscopicity.
The morphology of BC particles directly affects the HGF. As illustrated in Fig. 11, when the $\Delta D_{\mathrm{me}}$ was 18 and $22 \mathrm{~nm}$ for 100 and $150 \mathrm{~nm} \mathrm{BC}$ particles, the HGF decreased slightly to about 0.99 , suggesting that a thin layer of coating on $\mathrm{BC}$ particles decreased the particle diameter, even though a certain amount of water absorbed by BC particles increased the particle mass. The surface tension of the water layer produced an inward force on the "chain-like" branches of BC particles, leading to particle reconstruction and a more compact morphology. Such a change was also identified in laboratory studies (Weingartner et al., 1997; Tritscher et al., 2011; Qiu et al., 2012). In this study, the BC particles became spherical when $\Delta D_{\text {me }}$ was 30 and $40 \mathrm{~nm}$ for particles with initial $D_{\mathrm{m}}$ of 100 and $150 \mathrm{~nm}$, respectively (Peng et al., 2016). Therefore, when $\Delta D_{\text {me }}$ was large, the HGF value was not influenced by reconstruction.

\subsubsection{CCN measurements and $\kappa$ closure}

The $\mathrm{CCN}$ activation faction $\left(f_{\mathrm{CCN}}\right)$ of $\mathrm{BC}$ particles at different supersaturation during two typical experiments is illustrated in Fig. 11. Fresh BC particles were not activated even at very high supersaturation conditions $(0.7 \%)$. With ageing, $f_{\mathrm{CCN}}$ rapidly raised to nearly $100 \%$ at high supersaturation ( $0.7 \%$ for experiment 4 and $0.6 \%$ for experiment 6$)$. After several hours, BC particles became $\mathrm{CCN}$ at lower supersaturation. The $f_{\mathrm{CCN}}$ at 0.4 supersaturation (Fig. 11a in experiment 4 ) and 0.3 supersaturation (Fig. 11b in experiment 6) exceeded $50 \%$ before the end of these two experiments, suggesting that ageing increases the ability of $\mathrm{BC}$ particles to become CCN (Wittbom et al., 2014) and a large amount of coating results in activation at lower supersaturation.

To further investigate the hygroscopicity of $\mathrm{BC}$ particles and combine the measurements using HTDMA and CCN, we evaluated the hygroscopicity parameter, kappa $(\kappa)$ (Petters and Kreidenweis, 2007). The approximate relationship between the dry particle mass equivalent diameter $\left(D_{\mathrm{me}}\right)$, the critical saturation ratio $\left(S_{\mathrm{c}}\right)$ and the apparent $\kappa$ value of particles is described as 

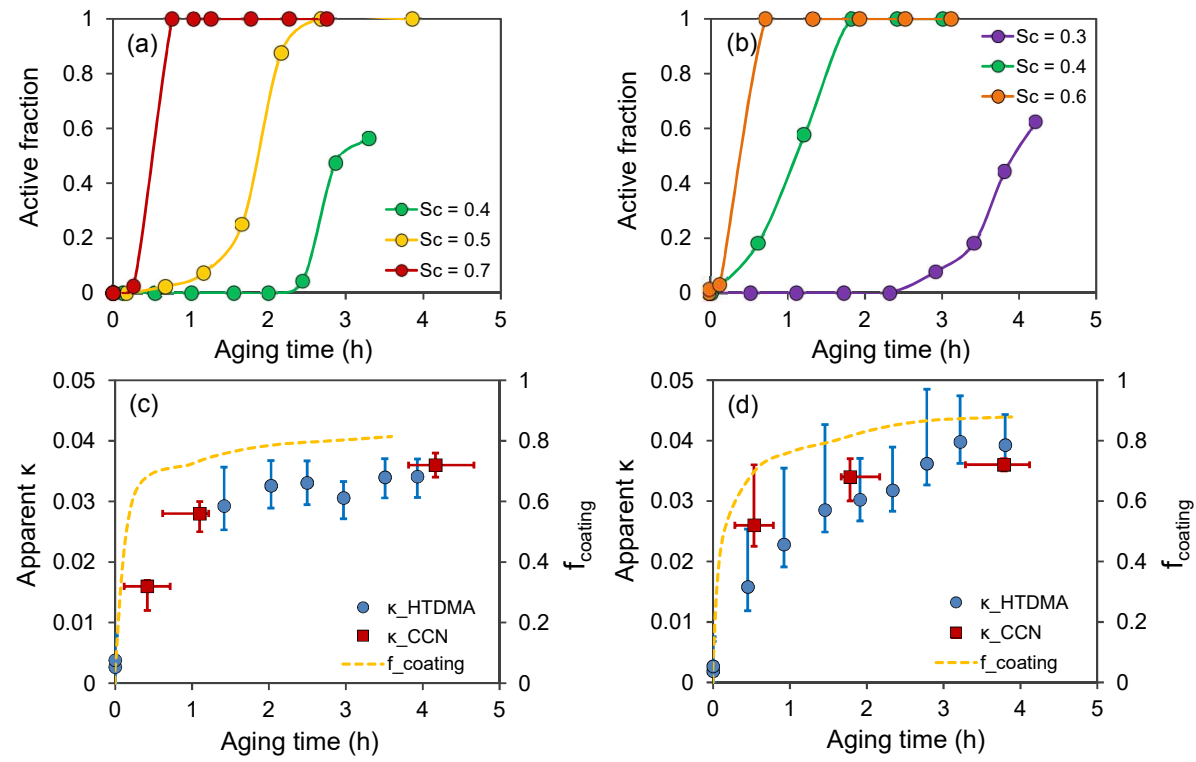

Figure 11. The active fraction of BC particles under diversified supersaturation (a, b) and the closure of apparent $\kappa$ for BC particles with initial diameter (c, d) during ageing in two typical experiments. Panels (a, c) are the results from experiment 4 with $100 \mathrm{~nm}$ BC particles and (b, d) represents experiment 6 with $150 \mathrm{~nm} \mathrm{BC}$ particles. Red square and blue circle in (c, d) represent the apparent $\kappa$ calculated using CCN counter data and HTDMA data, respectively. Yellow dashed line represents the fraction of coating materials on BC particles. The error bars of $\kappa_{-} \mathrm{CCN}$ and $\kappa_{-}$HTDMA represent the uncertainty in the calculation.

$\kappa=\frac{4 A^{3}}{27 D_{\mathrm{me}} \ln ^{2} S_{\mathrm{c}}}$,

where $A$ is a parameter that includes several features of the solvent.

$A=\frac{4 \sigma_{\mathrm{s} / \mathrm{a}} M_{\mathrm{w}}}{R T \rho_{\mathrm{W}}}$

$M_{\mathrm{w}}$ is the molecular weight of water, $\rho_{\mathrm{w}}$ is the density of water, $\sigma_{\mathrm{s} / \mathrm{a}}$ is the surface tension of the solution/air interface, $R$ is the universal gas constant, and $T$ is temperature.

In addition to the supersaturated condition, the $\kappa$ theory also adopts the form for the subsaturated condition, using the HGF from HTDMA measurement and RH:

$\frac{\mathrm{RH}}{\exp \left(\frac{A}{D_{\text {wet }}}\right)}=\frac{\mathrm{HGF}^{3}-1}{\mathrm{HGF}^{3}-(1-\kappa)}$,

where $D_{\text {wet }}$ is the wet diameter of particles.

The apparent $\kappa$ values of BC particles calculated by HTDMA $\left(\kappa \_\right.$HTDMA $)$and CCN $\left(\kappa \_C C N\right)$ are shown in Fig. 11. The $\kappa$ of fresh BC particles was near zero. With ageing, SOA coated on BC particles increased the $\kappa_{-}$HTDMA and $\kappa_{-}$CCN to approximately 0.04 , although the $\kappa_{-}$HTDMA and $\kappa_{-}$CCN exhibited difference features. A slightly higher $\kappa_{-} \mathrm{CCN}$ than $\kappa \_$HTDMA at the beginning of ageing was identified, attributed to the underestimation of HGF caused by the reconstruction of BC particles after humidification. Such a difference between $\kappa_{-} \mathrm{CCN}$ and $\kappa_{-}$HTDMA was also observed in previous studies (Tritscher et al., 2011; Martin et al., 2013). Nevertheless, the apparent $\kappa$ values from the two methods were comparable at the end of both experiments.

Assuming that a simple mixing rule is applicable to coated BC particles, the $\kappa$ for coating materials can be calculated based on the volume fraction of $\mathrm{BC}$ and SOA:

$\kappa=\sum_{i} \varepsilon_{i} \kappa_{i}$,

where $\varepsilon_{i}$ represents the volume fraction of species $i$. Since the SOA that formed inside the chamber was not highly hygroscopic, some of the SOA components might not be able to dissolve in water droplets (Petters and Kreidenweis, 2008), leading to the underestimation of the $\kappa$ values of the coating materials in this study.

The $\kappa$ values of the coating materials were 0.04 at the end of our experiments for both CCN and HTDMA method, much lower than that of ambient aerosols in Beijing (Gunthe et al., 2011; Wu et al., 2016) and those of SOA in previous chamber studies (Jimenez et al., 2009; Tritscher et al., 2011; Martin et al., 2013). As discussed above, the coating substances on $\mathrm{BC}$ particles were mainly SOA formed from photochemical oxidation. The $\kappa$ of SOA depends on the oxidation degree, which is correlated with the $\mathrm{O} / \mathrm{C}$ ratio (Jimenez et al., 2009; Massoli et al. 2010). The $\mathrm{O} / \mathrm{C}$ ratio of the coating SOA was 0.5 in our experiment, corresponding to the $\mathrm{O} / \mathrm{C}$ ratio of approximately 0.4 in Jimenez et al. (2009) and Massoli et al. (2010) due to the use of an updated AMS calibration method in this study. The $\kappa$ value of the coating 
materials here is in general slightly lower than that of SOA with similar oxidation degree $(\mathrm{O} / \mathrm{C}$ ratio) formed from different VOC precursors (Jimenez et al., 2009; Massoli et al. 2010). As mentioned above, the $\kappa$ values of the coating materials might be underestimated due to not accounting for the solubility of the SOA products. Also, our experiments represent the ageing of $\mathrm{BC}$ under typical urban condition, in which a variety of anthropogenic VOCs, i.e. toluene, xylene, TMB and small molecular PAHs, contribute significantly to the SOA formation. Some products of these VOC precursors may exhibit low hygroscopicity.

\section{Conclusions}

In this paper, we present measurements of ageing and hygroscopicity of BC particles in Beijing using the QUALITY chamber. The unique two sub-chamber design facilitates the evaluation of ageing of BC particles under ambient conditions, by mimicking the ambient gaseous concentrations without the presence of ambient aerosols. High UV transmission efficiency (50-60\%) and negligible wall loss of primary gaseous pollutants are shown for the chamber performance. The validation experiments demonstrate few differences in the primary gas concentrations, temperature and $\mathrm{RH}$ between the chamber and the atmosphere, suggesting that the chamber captures the evolution of ambient conditions. In addition, our results show sulfuric acid production correlated with $\mathrm{SO}_{2}$, indicating that the chamber successfully simulates photochemical-driven formation of low volatile gaseous species by the hydroxyl radical.

$\mathrm{BC}$ ageing experiments were performed using the QUALITY chamber in Beijing. Fast growth of BC particles (on average $26 \pm 11 \mathrm{~nm} \mathrm{~h}^{-1}$ ) was observed, and SOA was identified as the dominant component of the coating materials on BC particles, while inorganic species, such as sulfate and nitrate, were unimportant in our experimental condition and timescale.

The HGF of BC particles exhibited a very low value (1.021.08) after several hours of ageing. A slight decrease of HGF with a thin coating layer indicated reconstruction of $\mathrm{BC}$ particles after humidification. Also, a very low kappa value (0.035) for BC particles at both subsaturation and supersaturation conditions were found, with HTDMA and CCN measurements. Hence, our results indicate that initial photochemical ageing of BC particles leads to large modifications to morphology and optical properties, but does not appreciably alter the particle hygroscopicity in Beijing.

Data availability. The data presented in this paper are available from the author upon request (minu@pku.edu.cn).

\section{The Supplement related to this article is available online at https://doi.org/10.5194/acp-17-10333-2017- supplement.}

Competing interests. The authors declare that they have no conflict of interest.

Special issue statement. This article is part of the special issue "Regional transport and transformation of air pollution in eastern China". It is not associated with a conference.

Acknowledgements. This work was supported by the National Natural Science Foundation of China (91544214, 41421064), the National Basic Research Program, China Ministry of Science and Technology (Grant 2013CB228503, Grant 2013CB955801), National Natural Science Foundation of China (Grant 21190052), and the China Ministry of Environmental Protection's Special Funds for Scientific Research on Public Welfare (Grant 20130916). Renyi Zhang acknowledged support from the Robert A. Welch Foundation (Grant A-1417) and Houston Advanced Research Center. We thanked Wei Hu and Zhaoheng Gong for their assistance with the AMS data analysis, and Wentai Chen and Yue Li for providing VOC data.

Edited by: Zhanqing Li

Reviewed by: two anonymous referees

\section{References}

Bond, T. C., Doherty, S. J., Fahey, D. W., Forster, P. M., Berntsen, T., DeAngelo, B. J., Flanner, M. G., Ghan, S., Kärcher, B., Koch, D., Kinne, S., Kondo, Y., Quinn, P. K., Sarofim, M. C., Schultz, M. G., Schulz, M., Venkataraman, C., Zhang, H., Zhang, S., Bellouin, N., Guttikunda, S. K., Hopke, P. K., Jacobson, M. Z., Kaiser, J. W., Klimont, Z., Lohmann, U., Schwarz, J. P., Shindell, D., Storelvmo, T., Warren, S. G., and Zender, C. S.: Bounding the role of black carbon in the climate system: A scientific assessment, J. Geophys. Res.-Atmos., 118, 5380-5552, https://doi.org/10.1002/jgrd.50171, 2013.

Canagaratna, M. R., Jimenez, J. L., Kroll, J. H., Chen, Q., Kessler, S. H., Massoli, P., Hildebrandt Ruiz, L., Fortner, E., Williams, L. R., Wilson, K. R., Surratt, J. D., Donahue, N. M., Jayne, J. T., and Worsnop, D. R.: Elemental ratio measurements of organic compounds using aerosol mass spectrometry: characterization, improved calibration, and implications, Atmos. Chem. Phys., 15, 253-272, https://doi.org/10.5194/acp-15-253-2015, 2015.

Claeys, M.: Formation of Secondary Organic Aerosols Through Photooxidation of Isoprene, Science, 303, 1173-1176, https://doi.org/10.1126/science.1092805, 2004.

DeCarlo, P. F., Slowik, J. G., Worsnop, D. R., Davidovits, P., and Jimenez, J. L.: Particle Morphology and Density Characterization by Combined Mobility and Aerodynamic Diameter Measurements. Part 1: Theory, Aerosol Sci. Tech., 38, 1185-1205, https://doi.org/10.1080/027868290903907, 2004. 
DeCarlo, P. F., Kimmel, J. R., Trimborn, A., Northway, M. J., Jayne, J. T., Aiken, A. C., Gonin, M., Fuhrer, K., Horvath, T., Docherty, K. S., Worsnop, D. R., and Jimenez, J. L.: Field-deployable, high-resolution, time-of-flight aerosol mass spectrometer, Anal. Chem., 78, 8281-8289, https://doi.org/10.1021/ac061249n, 2006.

DeCarlo, P. F., Ulbrich, I. M., Crounse, J., de Foy, B., Dunlea, E. J., Aiken, A. C., Knapp, D., Weinheimer, A. J., Campos, T., Wennberg, P. O., and Jimenez, J. L.: Investigation of the sources and processing of organic aerosol over the Central Mexican Plateau from aircraft measurements during MILAGRO, Atmos. Chem. Phys., 10, 5257-5280, https://doi.org/10.5194/acp10-5257-2010, 2010.

Ervens, B., Turpin, B. J., and Weber, R. J.: Secondary organic aerosol formation in cloud droplets and aqueous particles (aqSOA): a review of laboratory, field and model studies, Atmos. Chem. Phys., 11, 11069-11102, https://doi.org/10.5194/acp-1111069-2011, 2011.

Fortner, E. C., Zhao, J., and Zhang, R. Y.: Development of ion driftchemical ionization mass spectrometry, Anal. Chem., 76, 54365440, https://doi.org/10.1021/ac0493222, 2004.

Gunthe, S. S., Rose, D., Su, H., Garland, R. M., Achtert, P., Nowak, A., Wiedensohler, A., Kuwata, M., Takegawa, N., Kondo, Y., Hu, M., Shao, M., Zhu, T., Andreae, M. O., and Pöschl, U.: Cloud condensation nuclei (CCN) from fresh and aged air pollution in the megacity region of Beijing, Atmos. Chem. Phys., 11, 1102311039, https://doi.org/10.5194/acp-11-11023-2011, 2011.

Guo, S., Hu, M., Wang, Z. B., Slanina, J., and Zhao, Y. L.: Sizeresolved aerosol water-soluble ionic compositions in the summer of Beijing: implication of regional secondary formation, Atmos. Chem. Phys., 10, 947-959, https://doi.org/10.5194/acp-10-9472010, 2010.

Guo, S., Hu, M., Zamora, M. L., Peng, J., Shang, D., Zheng, J., Du, Z., Wu, Z., Shao, M., Zeng, L., Molina, M. J., and Zhang, R.: Elucidating severe urban haze formation in China, P. Natl. Acad. Sci. USA, 111, 17373-17378, https://doi.org/10.1073/pnas.1419604111, 2014.

Guo, S., Hu, M., Lin, Y., Gomez-Hernandez, M., Zamora, M. L., Peng, J. F., Collins, D. R., and Zhang, R. Y.: OH-Initiated Oxidation of m-Xylene on Black Carbon Aging, Environ. Sci. Technol., 50, 8605-8612, https://doi.org/10.1021/acs.est.6b01272, 2016.

He, L.-Y., Huang, X.-F., Xue, L., Hu, M., Lin, Y., Zheng, J., Zhang, R., and Zhang, Y.-H.: Submicron aerosol analysis and organic source apportionment in an urban atmosphere in Pearl River Delta of China using high-resolution aerosol mass spectrometry, J. Geophys. Res., 116, D12304, https://doi.org/10.1029/2010JD014566, 2011.

Hu, M., Peng, J., Sun, K., Yue, D., Guo, S., Wiedensohler, A., and Wu, Z.: Estimation of Size-Resolved Ambient Particle Density Based on the Measurement of Aerosol Number, Mass, and Chemical Size Distributions in the Winter in Beijing, Environ. Sci. Technol., 46, 9941-9947, https://doi.org/10.1021/es204073t, 2012.

Hu, W., Hu, M., Hu, W., Jimenez, J. L., Yuan, B., Chen, W., Wang, M., Wu, Y., Chen, C., Wang, Z., Peng, J., Zeng, L., and Shao, M.: Chemical composition, sources and aging process of sub-micron aerosols in Beijing: contrast between sum- mer and winter, J. Geophys. Res.-Atmos., 121, 1955-1977 https://doi.org/10.1002/2015jd024020, 2016.

Huang, X.-F., He, L.-Y., Hu, M., Canagaratna, M. R., Sun, Y., Zhang, Q., Zhu, T., Xue, L., Zeng, L.-W., Liu, X.-G., Zhang, Y.-H., Jayne, J. T., Ng, N. L., and Worsnop, D. R.: Highly time-resolved chemical characterization of atmospheric submicron particles during 2008 Beijing Olympic Games using an Aerodyne High-Resolution Aerosol Mass Spectrometer, Atmos. Chem. Phys., 10, 8933-8945, https://doi.org/10.5194/acp-108933-2010, 2010.

IPCC: Intergovernmental Panel on Climate Change, Climate Change 2013: The Physical Science Basis, Cambridge Univ. Press, Cambridge, UK, 2013.

Jacobson, M. Z.: Strong radiative heating due to the mixing state of black carbon in atmospheric aerosols, Nature, 409, 695-697, https://doi.org/10.1038/35055518, 2001.

Jimenez, J. L., Canagaratna, M. R., Donahue, N. M., Prevot, A. S. H., Zhang, Q., Kroll, J. H., DeCarlo, P. F., Allan, J. D., Coe, H., Ng, N. L., Aiken, A. C., Docherty, K. S., Ulbrich, I. M., Grieshop, A. P., Robinson, A. L., Duplissy, J., Smith, J. D., Wilson, K. R., Lanz, V. A., Hueglin, C., Sun, Y. L., Tian, J., Laaksonen, A., Raatikainen, T., Rautiainen, J., Vaattovaara, P., Ehn, M., Kulmala, M., Tomlinson, J. M., Collins, D. R., Cubison, M. J., Dunlea, J., Huffman, J. A., Onasch, T. B., Alfarra, M. R., Williams, P. I., Bower, K., Kondo, Y., Schneider, J., Drewnick, F., Borrmann, S., Weimer, S., Demerjian, K., Salcedo, D., Cottrell, L., Griffin, R., Takami, A., Miyoshi, T., Hatakeyama, S., Shimono, A., Sun, J. Y., Zhang, Y. M., Dzepina, K., Kimmel, J. R., Sueper, D., Jayne, J. T., Herndon, S. C., Trimborn, A. M., Williams, L. R., Wood, E. C., Middlebrook, A. M., Kolb, C. E., Baltensperger, U., and Worsnop, D. R.: Evolution of Organic Aerosols in the Atmosphere, Science, 326, 1525-1529, https://doi.org/10.1126/science.1180353, 2009.

Kalberer, M.: Identification of Polymers as Major Components of Atmospheric Organic Aerosols, Science, 303, 1659-1662, https://doi.org/10.1126/science.1092185, 2004.

Khalizov, A. F., Xue, H., and Zhang, R.: Enhanced light absorption and scattering by carbon soot aerosols internally mixed with sulfuric acid, J. Phys. Chem., 113, 1066-1074, https://doi.org/10.1021/jp807531n, 2009a.

Khalizov, A. F., Zhang, R., Zhang, D., Xue, H., Pagels, J., and McMurry, P. H.: Formation of highly hygroscopic soot aerosols upon internal mixing with sulfuric acid vapor, J. Geophys. Res., 114, D05208, https://doi.org/10.1029/2008jd010595, 2009 b.

Khalizov, A. F., Lin, Y., Qiu, C., Guo, S., Collins, D., and Zhang, R.: Role of OH-Initiated Oxidation of Isoprene in Aging of Combustion Soot, Environ. Sci. Technol., 47, 2254-2263, https://doi.org/10.1021/es3045339, 2013.

Kuwata, M., Kondo, Y., Mochida, M., Takegawa, N., and Kawamura, K.: Dependence of CCN activity of less volatile particles on the amount of coating observed in Tokyo, J. Geophys. Res., 112, D11207, https://doi.org/10.1029/2006jd007758, 2007.

Liu, S., Aiken, A. C., Gorkowski, K., Dubey, M. K., Cappa, C. D., Williams, L. R., Herndon, S. C., Massoli, P., Fortner, E. C., Chhabra, P. S., Brooks, W. A., Onasch, T. B., Jayne, J. T., Worsnop, D. R., China, S., Sharma, N., Mazzoleni, C., Xu, L., Ng, N. L., Liu, D., Allan, J. D., Lee, J. D., Fleming, Z. L., Mohr, C., Zotter, P., Szidat, S., and Prevot, A. S. H.: Enhanced light absorption by mixed source black and 
brown carbon particles in UK winter, Nat. Commun., 6, 8435, https://doi.org/10.1038/Ncomms9435, 2015.

Liu, Y., Shao, M., Fu, L. L., Lu, S. H., Zeng, L. M., and Tang, D. G.: Source profiles of volatile organic compounds (VOCs) measured in China: Part I, Atmos. Environ., 42, 6247-6260, https://doi.org/10.1016/j.atmosenv.2008.01.070, 2008.

Ma, Y., Brooks, S. D., Vidaurre, G., Khalizov, A. F., Wang, L., and Zhang, R.: Rapid modification of cloud-nucleating ability of aerosols by biogenic emissions, Geophys. Res. Lett., 40, 62936297, https://doi.org/10.1002/2013gl057895, 2013.

Martin, M., Tritscher, T., Jurányi, Z., Heringa, M. F., Sierau, B., Weingartner, E., Chirico, R., Gysel, M., Prévôt, A. S. H., Baltensperger, U., and Lohmann, U.: Hygroscopic properties of fresh and aged wood burning particles, J. Aerosol Sci., 56, 1529, https://doi.org/10.1016/j.jaerosci.2012.08.006, 2013.

Massoli, P., Lambe, A. T., Ahern, A. T., Williams, L. R., Ehn, M., Mikkilä, J., Canagaratna, M. R., Brune, W. H., Onasch, T. B., Jayne, J. T., Petäjä, T., Kulmala, M., Laaksonen, A., Kolb, C. E., Davidovits, P., and Worsnop, D. R.: Relationship between aerosol oxidation level and hygroscopic properties of laboratory generated secondary organic aerosol (SOA) particles. Geophys. Res. Lett., 37, L24801, https://doi.org/10.1029/2010GL045258, 2010.

Moffet, R. C. and Prather, K. A.: In-situ measurements of the mixing state and optical properties of soot with implications for radiative forcing estimates, P. Natl. Acad. Sci. USA, 106, 11872 11877, https://doi.org/10.1073/pnas.0900040106, 2009.

Pagels, J., McMurry, P. H., Khalizov, A. F., and Zhang, R.: Processing of soot by controlled sulphuric acid and water condensationMass and mobility relationship, Aerosol Sci. Tech. 43, 629-640, 2009.

Peng, J., Hu, M., Du, Z., Wang, Y., Zheng, J., Zhang, W., Yang, Y., Qin, Y., Zheng, R., Xiao, Y., Wu, Y., Lu, S., Wu, Z., Guo, S., Mao, H., and Shuai, S.: Gasoline aromatic: a critical determinant of urban secondary organic aerosol formation, Atmos. Chem. Phys. Discuss., https://doi.org/10.5194/acp-2017-254, in review, 2017.

Peng, J. F., Hu, M., Wang, Z. B., Huang, X. F., Kumar, P., Wu, Z. J., Guo, S., Yue, D. L., Shang, D. J., Zheng, Z., and He, L. Y.: Submicron aerosols at thirteen diversified sites in China: size distribution, new particle formation and corresponding contribution to cloud condensation nuclei production, Atmos. Chem. Phys., 14, 10249-10265, https://doi.org/10.5194/acp-14-102492014, 2014.

Peng, J. F., Hu, M., Guo, S., Du, Z. F., Zheng, J., Shang, D. J., Zamora, M. L., Zeng, L. M., Shao, M., Wu, Y. S., Zheng, J., Wang, Y., Glen, C. R., Collins, D. R., Molina, M. J., and Zhang, R. Y.: Markedly enhanced absorption and direct radiative forcing of black carbon under polluted urban environments, P. Natl. Acad. Sci. USA, 113, 4266-4271, https://doi.org/10.1073/pnas.1602310113, 2016.

Petters, M. D. and Kreidenweis, S. M.: A single parameter representation of hygroscopic growth and cloud condensation nucleus activity, Atmos. Chem. Phys., 7, 1961-1971, https://doi.org/10.5194/acp-7-1961-2007, 2007.

Petters, M. D. and Kreidenweis, S. M.: A single parameter representation of hygroscopic growth and cloud condensation nucleus activity - Part 2: Including solubility, Atmos. Chem. Phys., 8, 6273-6279, https://doi.org/10.5194/acp-8-6273-2008, 2008.
Qiu, C. and Zhang, R.: Multiphase chemistry of atmospheric amines, Phys. Chem. Chem. Phys. 15, 5738-5752, https://doi.org/10.1039/C3CP43446J, 2013.

Qiu, C., Khalizov, A. F., and Zhang, R. Y.: Soot Aging from OHInitiated Oxidation of Toluene, Environ. Sci. Technol., 46, 9464 9472, https://doi.org/10.1021/Es301883y, 2012.

Reed, R. C.: Observations of secondary organic aerosol production and soot aging under atmospheric conditions using a novel new environmental aerosol chamber, $\mathrm{PhD}$ dissertation, Texas A\&M Univ, College Station, TX, 2010.

Ruehl, C. R., Davies, J. F., and Wilson, K. R.: An interfacial mechanism for cloud droplet formation on organic aerosols, Science, 351, 1447-1450, https://doi.org/10.1126/science.aad4889, 2016.

Saathoff, H., Naumann, K. H., Schnaiter, M., Schöck, W., Möhler, O., Schurath, U., Weingartner, E., Gysel, M., and Baltensperger, U.: Coating of soot and $\left(\mathrm{NH}_{4}\right)_{2} \mathrm{SO}_{4}$ particles by ozonolysis products of $\alpha$-pinene, J. Aerosol Sci., 34, 1297-1321, https://doi.org/10.1016/s0021-8502(03)00364-1, 2003.

Santoro, R. J., Semerjian, H. G., and Dobbins, R. A.: Soot Particle Measurements in Diffusion Flames, Combust. Flame, 51, 203218, 1983.

Swietlicki, E., Hansson, H. C., HÄMeri, K., Svenningsson, B., Massling, A., McFiggans, G., McMurry, P. H., PetÄJÄ, T., Tunved, P., Gysel, M., Topping, D., Weingartner, E., Baltensperger, U., Rissler, J., Wiedensohler, A., and Kulmala, M.: Hygroscopic properties of submicrometer atmospheric aerosol particles measured with H-TDMA instruments in various environments - a review, Tellus B, 60, 432-469, https://doi.org/10.1111/j.1600-0889.2008.00350.x, 2008.

Tritscher, T., Jurányi, Z., Martin, M., Chirico, R., Gysel, M., Heringa, M. F., DeCarlo, P. F., Sierau, B., Prévôt, A. S. H., Weingartner, E., and Baltensperger, U.: Changes of hygroscopicity and morphology during ageing of diesel soot, Environ. Res. Lett., 6, 034026, https://doi.org/10.1088/1748-9326/6/3/034026, 2011.

Wang, G. H., Zhang, R. Y., Gomez, M. E., Yang, L. X., Zamora, M. L., Hu, M., Lin, Y., Peng, J. F., Guo, S., Meng, J. J., Li, J. J., Cheng, C. L., Hu, T. F., Ren, Y. Q., Wang, Y. S., Gao, J., Cao, J. J., An, Z. S., Zhou, W. J., Li, G. H., Wang, J. Y., Tian, P. F., Marrero-Ortiz, W., Secrest, J., Du, Z. F., Zheng, J., Shang, D. J., Zeng, L. M., Shao, M., Wang, W. G., Huang, Y., Wang, Y., Zhu, Y. J., Li, Y. X., Hu, J. X., Pan, B., Cai, L., Cheng, Y. T., Ji, Y. M., Zhang, F., Rosenfeld, D., Liss, P. S., Duce, R. A., Kolb, C. E., and Molina, M. J.: Persistent sulfate formation from London Fog to Chinese haze, P. Natl. Acad. Sci. USA, 113, 13630-13635, https://doi.org/10.1073/pnas.1616540113, 2016.

Wang, L., Khalizov, A. F., Zheng, J., Xu, W., Ma, Y., Lal, V., and Zhang, R. Y.: Atmospheric nanoparticles formed from heterogeneous reactions of organics, Nat. Geosci., 3, 238-242, https://doi.org/10.1038/NGEO778, 2010.

Wang, Y., Wan, Q., Meng, W., Liao, F., Tan, H., and Zhang, R.: Long-term impacts of aerosols on precipitation and lightning over the Pearl River Delta megacity area in China, Atmos. Chem. Phys., 11, 12421-12436, https://doi.org/10.5194/acp-11-124212011, 2011.

Wang, Y., Khalizov, A., Levy, M., and Zhang, R.: Light absorbing aerosols and their atmospheric impacts, Atmos. Environ. 81, 713-715, https://doi.org/10.1016/j.atmosenv.2013.09.034, 2013.

Weingartner, E., Burtscher, H., and Baltensperger, U.: Hygroscopic properties of carbon and diesel soot particles, Atmos. Environ., 
31, 2311-2327, https://doi.org/10.1016/S1352-2310(97)00023X, 1997.

Wittbom, C., Eriksson, A. C., Rissler, J., Carlsson, J. E., Roldin, P., Nordin, E. Z., Nilsson, P. T., Swietlicki, E., Pagels, J. H., and Svenningsson, B.: Cloud droplet activity changes of soot aerosol upon smog chamber ageing, Atmos. Chem. Phys., 14, 9831-9854, https://doi.org/10.5194/acp-14-9831-2014, 2014.

Wu, Z. J., Zheng, J., Shang, D. J., Du, Z. F., Wu, Y. S., Zeng, L. M., Wiedensohler, A., and Hu, M.: Particle hygroscopicity and its link to chemical composition in the urban atmosphere of Beijing, China, during summertime, Atmos. Chem. Phys., 16, 11231138, https://doi.org/10.5194/acp-16-1123-2016, 2016.

Xue, H., Khalizov, A. F., Wang, L., Zheng, J., and Zhang, R.: Effects of dicarboxylic acid coating on the optical properties of soot, Phys. Chem. Chem. Phys., 11, 7865-7875, https://doi.org/10.1039/b904129j, 2009a.

Xue, H., Khalizov, A. F., and Zhang, R.: Effects of coating of dicarboxylic acids on the mass-mobility relationship of soot particles, Environ. Sci. Technol., 43, 2787-2792, https://doi.org/10.1021/es803287v, 2009b.

Yuan, T., Li, Z., Zhang, R., and Fan, J.: Increase of cloud droplet size with aerosol optical depth: An observation and modeling study, J. Geophys. Res., 113, D04201, https://doi.org/10.1029/2007JD008632, 2008.

Zhang, D. and Zhang, R.: Laboratory investigation of heterogeneous interaction of sulfuric acid with soot, Environ. Sci. Technol., 39, 5722-5727, https://doi.org/10.1021/es050372d, 2005.

Zhang, R., Suh, I., Lei, W., Clinkenbeard, A. D., and North, S. W.: Kinetic studies of $\mathrm{OH}$-initiated reactions of isoprene, J. Geophys. Res., 105, 24627-24635, https://doi.org/10.1029/2000JD900330, 2000.

Zhang, R., Khalizov, A. F., Pagels, J., Zhang, D., Xue, H., and McMurry, P. H.: Variability in morphology, hygroscopicity, and optical properties of soot aerosols during atmospheric processing, P. Natl. Acad. Sci. USA, 105, 10291-10296, https://doi.org/10.1073/pnas.0804860105, 2008.

Zhang, R., Khalizov, A. F., Wang, L., Hu, M., and Xu, W.: Nucleation and growth of nanoparticles in the atmosphere, Chem. Rev., 112, 1957-2011, https://doi.org/10.1021/cr2001756, 2012.

Zhang, R. Y., Suh, I., Zhao, J., Zhang, D., Fortner, E. C., Tie, X. X., Molina, L. T., and Molina, M. J.: Atmospheric new particle formation enhanced by organic acids, Science, 304, 1487-1490, https://doi.org/10.1126/science.1095139, 2004.
Zhang, R. Y., Wang, G. H., Guo, S., Zarnora, M. L., Ying, Q., Lin, Y., Wang, W. G., Hu, M., and Wang, Y.: Formation of Urban Fine Particulate Matter, Chem. Rev., 115, 3803-3855, https://doi.org/10.1021/acs.chemrev.5b00067, 2015.

Zhao, J., Levitt, N. P., Zhang, R., and Chen, J.: Heterogeneous reactions of methylglyoxal in acidic media: Implications for secondary organic aerosol formation, Environ. Sci. Technol., 40, 7682-7687, https://doi.org/10.1021/es060610k, 2006.

Zhao, J., Khalizov, A.F., Zhang, R., and McGraw, R.: Hydrogen bonding interaction of molecular complexes and clusters of aerosol nucleation precursors, J. Phys. Chem., 113, 680-689, https://doi.org/10.1021/jp806693r, 2009.

Zhao, P. S., Dong, F., He, D., Zhao, X. J., Zhang, X. L., Zhang, W. Z., Yao, Q., and Liu, H. Y.: Characteristics of concentrations and chemical compositions for $\mathrm{PM}_{2.5}$ in the region of Beijing, Tianjin, and Hebei, China, Atmos. Chem. Phys., 13, 4631-4644, https://doi.org/10.5194/acp-13-4631-2013, 2013.

Zheng, J., Zhang, R., Fortner, E. C., Volkamer, R. M., Molina, L., Aiken, A. C., Jimenez, J. L., Gaeggeler, K., Dommen, J., Dusanter, S., Stevens, P. S., and Tie, X.: Measurements of $\mathrm{HNO}_{3}$ and $\mathrm{N}_{2} \mathrm{O}_{5}$ using ion drift-chemical ionization mass spectrometry during the MILAGRO/MCMA-2006 campaign, Atmos. Chem. Phys., 8, 6823-6838, https://doi.org/10.5194/acp-8-6823-2008, 2008.

Zheng, J., Khalizov, A., Wang, L., and Zhang, R. Y.: Atmospheric Pressure-Ion Drift Chemical Ionization Mass Spectrometry for Detection of Trace Gas Species, Anal. Chem., 82, 7302-7308, https://doi.org/10.1021/ac101253n, 2010. 